\title{
Key Factors Influencing Rates of Heterotrophic Sulfate Reduction in Active Seafloor Hydrothermal Massive Sulfide Deposits
}

\author{
Kiana L. Frank ${ }^{1,2 *}$, Karyn L. Rogers ${ }^{3}$, Daniel R. Rogers ${ }^{4,5}$, David T. Johnston ${ }^{5}$ and \\ Peter R. Girguis ${ }^{6}$
}

${ }^{1}$ Department of Molecular Biology, Harvard University, Cambridge, MA, USA, ${ }^{2}$ Department of Oceanography, University of Hawaii, Honolulu, HI, USA, ${ }^{3}$ Department of Earth and Environmental Sciences, Rensselaer Polytechnic Institute, Troy, NY, USA, ${ }^{4}$ Department of Chemistry, Stonehill College, Easton, MA, USA, ${ }^{5}$ Department of Earth and Planetary Sciences, Harvard University, Cambridge, MA, USA, ${ }^{6}$ Department of Organismic and Evolutionary Biology, Harvard University, Cambridge, MA, USA

\section{OPEN ACCESS}

Edited by:

Cara M. Santelli,

University of Minnesota, USA

Reviewed by:

Andreas Teske,

University of North Carolina at Chapel

Hill, USA

Margaret Kingston Tivey,

Woods Hole Oceanographic

Institution, USA

${ }^{*}$ Correspondence:

Kiana L. Frank

klfrank@hawaii.edu

Specialty section:

This article was submitted to

Extreme Microbiology,

a section of the journal

Frontiers in Microbiology

Received: 15 July 2015 Accepted: 04 December 2015 Published: 22 December 2015

Citation:

Frank KL, Rogers KL, Rogers DR, Johnston DT and Girguis PR (2015)

Key Factors Influencing Rates of Heterotrophic Sulfate Reduction in Active Seafloor Hydrothermal Massive Sulfide Deposits.

Front. Microbiol. 6:1449.

doi: 10.3389/fmicb.2015.01449
Hydrothermal vents are thermally and geochemically dynamic habitats, and the organisms therein are subject to steep gradients in temperature and chemistry. To date, the influence of these environmental dynamics on microbial sulfate reduction has not been well constrained. Here, via multivariate experiments, we evaluate the effects of key environmental variables (temperature, $\mathrm{pH}, \mathrm{H}_{2} \mathrm{~S}, \mathrm{SO}_{4}^{2-}$, DOC) on sulfate reduction rates and metabolic energy yields in material recovered from a hydrothermal flange from the Grotto edifice in the Main Endeavor Field, Juan de Fuca Ridge. Sulfate reduction was measured in batch reactions across a range of physico-chemical conditions. Temperature and $\mathrm{pH}$ were the strongest stimuli, and maximum sulfate reduction rates were observed at $50^{\circ} \mathrm{C}$ and $\mathrm{pH} 6$, suggesting that the in situ community of sulfate-reducing organisms in Grotto flanges may be most active in a slightly acidic and moderate thermal/chemical regime. At $\mathrm{pH} 4$, sulfate reduction rates increased with sulfide concentrations most likely due to the mitigation of metal toxicity. While substrate concentrations also influenced sulfate reduction rates, energy-rich conditions muted the effect of metabolic energetics on sulfate reduction rates. We posit that variability in sulfate reduction rates reflect the response of the active microbial consortia to environmental constraints on in situ microbial physiology, toxicity, and the type and extent of energy limitation. These experiments help to constrain models of the spatial contribution of heterotrophic sulfate reduction within the complex gradients inherent to seafloor hydrothermal deposits.

Keywords: sulfate reduction, rate, energetics, hydrothermal deposits, microbial activity

\section{INTRODUCTION}

Sulfate-reducing bacteria and archaea gain energy by mediating the anaerobic oxidation of organic and inorganic substrates using sulfate as an electron acceptor. The electron donors utilized by sulfate reducers are quite variable, ranging from molecular hydrogen to aromatic compounds, although low molecular weight organic compounds including acetate, lactate, pyruvate, and ethanol 
(prevalent in anaerobic environments as a result of the fermentative breakdown of biomass) are commonly used (Amend et al., 2004; Rabus et al., 2006; Tarpgaard et al., 2011).

Due to the high concentration of sulfate in seawater $(28 \mathrm{mM}$; Dittmar, 1884), sulfate reduction (or SR) is an ubiquitous metabolism in hypoxic to anoxic marine habitats (Muyzer and Stams, 2008) such as oxygen minimum zone waters (Canfield et al., 2010), marine sediments (Kallmeyer et al., 2002; Robador et al., 2009), hydrocarbon seeps (Joye et al., 2004; Orcutt et al., 2005), marine hydrothermal vents (Jørgensen et al., 1992; Elsgaard et al., 1994a; Weber and Jørgensen, 2002; Frank et al., 2013), and the deep subsurface (D'Hondt et al., 2004; Engelen et al., 2008; Robador et al., 2015). As such, SR likely has a significant impact on the global carbon budget (Westrich and Berner, 1984; Canfield, 1989). Among 33 phylogenetically diverse sulfate-reducing microbial isolates, cell-specific SR rates vary by orders of magnitude in their respective thermal regimes $(0.9 \mathrm{fmol}$ cell $^{-1}$ day $^{-1}$ for Desulfospira joergensenii to $4340 \mathrm{fmol} \mathrm{cell}^{-1}$ day $^{-1}$ for Desulfohalobium retbaense; Detmers et al., 2001). In marine sediments, estimates of cell-specific SR rates range from $10^{-4}$ to $10^{0} \mathrm{fmol} \mathrm{cell}^{-1} \mathrm{day}^{-1}$ and are often lower than those of pure cultures by orders of magnitude (Jørgensen and Bak, 1991; Ravenschlag et al., 2000; Orcutt et al., 2005; Leloup et al., 2007, 2009; Holmkvist et al., 2011a,b). SR rates have also been shown to be highly heterogeneous within marine sediments due to variations in substrate and organic carbon availability, as well as other geochemical and physical factors (Canfield, 1989; Isaksen et al., 1994; Kallmeyer et al., 2002; Orcutt et al., 2005; Fike et al., 2008; Treude et al., 2009; Holmkvist et al., 2011a).

SR has been proposed to be one of the most thermodynamically favorable metabolic processes in marine hydrothermal ecosystems (McCollom and Shock, 1997; Tivey, 2004) because of the relative abundance of sulfate as an oxidant, as well as the relative abundance of appropriate reductants. Indeed, many sulfate-reducing microorganisms have been isolated from deep-sea hydrothermal ecosystems (Huber et al., 1997; Jeanthon et al., 2002; Alazard et al., 2003; Audiffrin et al., 2003). Data on the mass-specific SR rates in hydrothermalinfluenced sediments (25-6600 nmol g-1 day-1, assuming an average sediment density of $2 \mathrm{~g} \mathrm{~cm}^{-3}$; Elsgaard et al., 1994a,b; Weber and Jørgensen, 2002; Kallmeyer and Boetius, 2004), sulfide deposits (16-2700 $\mathrm{nmol} \mathrm{g}^{-1}$ day $^{-1}$, Frank et al., 2013), and basaltic fluids $\left(0.01-0.05 \mathrm{nmol} \mathrm{ml}^{-1} \mathrm{day}^{-1}\right.$, Robador et al., 2015) underscore the biogeochemical and ecological relevance of microbial sulfate reduction in deep-sea hydrothermal ecosystems.

At hydrothermal vents, structures called chimneys develop as hydrothermal fluid mixes with cold seawater, providing a unique if not ideal habitat for a variety of bacteria and archaea that rely on vent- and seawater-derived compounds (Schrenk et al., 2003). However, the microorganisms within these porous mineral deposits are exposed, in varying degrees, to the dynamic and combined effects of high temperature, low $\mathrm{pH}$, high concentrations of hydrogen sulfide, fluctuating amounts of carbon, and varying energy sources. Previous studies reveal differences in prokaryotic populations among individual sulfide deposits (Harmsen et al., 1997; Takai et al., 2001; Schrenk et al.,
2003; Kormas et al., 2006; Pagé et al., 2008), but we know less about how physico-chemical gradients influence the rates of most key microbial metabolisms, including SR, within the walls of actively venting hydrothermal chimney structures.

The metabolic energy available for SR is likely influenced by the specific composition of the end-member fluids and ambient seawater (Tivey, 1995, 2004; Zhu et al., 2007) as well as temperature, among other factors. Microbial SR rates in hydrothermal vent systems are governed by a combination of thermodynamic driving forces and the kinetics of catabolic reactions. In energy-limited systems, metabolic reaction rates tend to decrease proportionally with catabolic energy yields, and the thermodynamic factor in the complete rate equation has been modeled either as a function of the energetic costs of ATP synthesis (Jin and Bethke, 2005) or the energetic requirements of maintaining a membrane potential (LaRowe et al., 2012). Application of these models to SR rates in hydrothermal vent environments and marine sediments suggests that SR rates can be significantly impacted by thermodynamic driving forces when substrates (e.g., $\mathrm{SO}_{4}^{2-}, \mathrm{CH}_{4}$, acetate) are limiting (Jin and Bethke, 2005; LaRowe et al., 2012). However, in environments with non-limiting sulfate or DOC concentrations, such as the experiments described here, heterotrophic SR rates can be modeled with standard Michaelis-Menten kinetics (Jin and Bethke, 2005). Even then, kinetic models depend on metabolismand species-specific model parameters (Jin and Bethke, 2005; LaRowe et al., 2012). Model-predicted rates of hydrogenotrophic $\mathrm{SR}$ in hydrothermal chimneys $\left(800 \mathrm{pmol} \mathrm{cm}^{3}\right.$ day $^{-1}$; LaRowe et al., 2014) are two to four orders of magnitude less than heterotrophic SR rates reported from Middle Valley chimneys (Frank et al., 2013), suggesting that kinetic models do not adequately capture the complexities of the natural environment. Although both thermodynamics and kinetics are functions of the physico-geochemical environment, the extent to which environmental factors-and their dynamics_influence SR rates remains unknown in hydrothermal chimneys and must be experimentally determined.

To better understand the parameters that affect SR rates within actively venting hydrothermal chimneys, we conducted a series of experiments that examined rates of microbial heterotrophic SR in batch incubations over a range of environmentally relevant chemical conditions $\left(\mathrm{pH}, \mathrm{H}_{2} \mathrm{~S}, \mathrm{SO}_{4}^{2-}\right.$, and organic carbon) and temperatures $\left(4,50\right.$, and $\left.90^{\circ} \mathrm{C}\right)$ from hydrothermal flange recovered from the Grotto edifice at the Main Endeavor Field, Juan de Fuca Ridge. This vent was specifically selected to be the focus of this study because its geology, mineralogy (pyrrhotite and pyrite), and end-member fluid chemistry ( $\mathrm{pH}$ of $4.2,12.6 \mathrm{mmol} \mathrm{kg}^{-1} \mathrm{CO}_{2}, 633 \mu \mathrm{mol} \mathrm{kg}{ }^{-1} \mathrm{NH}_{3}, 5.4 \mathrm{mmol} \mathrm{kg}^{-1}$ $\mathrm{H}_{2} \mathrm{~S}, 11 \mu \mathrm{M}$ DOC) have been extensively studied over the past decade (Tivey and Delaney, 1986; Delaney et al., 1992; Butterfield et al., 1994; Tivey et al., 1999, 2002; Tivey, 2004; Lang et al., 2006; Zhu et al., 2007). While models infer that sulfate concentration may govern SR within sulfide deposits, the discrepancies between modeled and empirically derived rates lead us to conclude that other factors may be responsible for the observed SR rates. We therefore posit that SR rates in sulfide deposits are controlled by other factors, such as hydrogen sulfide concentration, $\mathrm{pH}$, or 
organic carbon availability. Here we present empirical evidence for SR activity within active hydrothermal chimneys and quantitatively constrain the magnitude of net heterotrophic SR activity across a gradient of environmentally-relevant physicochemical regimes.

\section{MATERIALS AND METHODS}

\section{Geologic Setting and Sampling of Hydrothermal Sulfide Deposits}

The Main Endeavor vent field is located at $47^{\circ} 57^{\prime} \mathrm{N}$ and $129^{\circ} 06 \mathrm{~W}$ (Tivey and Delaney, 1986) at a depth of $2220 \mathrm{~m}$, the most shallow portion of the Endeavor segment of the Juan de Fuca ridge. This vent field is comparable in size and quantity of hydrothermal chimneys to most other hydrothermal areas, and is characterized by many ( $>15$ ) large steep-walled active sulfide deposits (containing multiple high temperature spires and diffusing flanges) surrounded by a scattering of smaller inactive hydrothermal sulfide deposits in a roughly $400 \mathrm{~m}^{2}$ area (Delaney et al., 1992; Robigou et al., 1993).

A single massive piece of hydrothermal deposit $(\sim 100 \mathrm{~kg}$ in weight) was recovered from a flange on the Grotto vent $(47.949,-129.098)$ at a depth of $2188.3 \mathrm{~m}$ (Dive J2-575, AT-18$08, R / V$ Atlantis) and brought up to the surface in the basket of the ROV Jason II. This sample will be hereafter referred to as a "flange." Once on board ship, tubeworms and other macrofauna were removed from the samples and the large pieces were broken into more manageable fragments $\left(\sim 10-20 \mathrm{~cm}^{3}\right)$ with a flame-sterilized chisel and sledgehammer, with the user wearing sterile nitrile gloves. Samples were quickly transferred to $0.2 \mu \mathrm{m}$-filtered anaerobic (nitrogen-sparged) seawater. Samples were further broken down into smaller sizes while in anaerobic water, and subsamples from the interior of the fragments were immediately transferred to gastight jars (Freund Container Inc.) filled with sterile anaerobic seawater containing $2 \mathrm{mM}$ sodium sulfide at $\mathrm{pH} 6$, and stored at $4^{\circ} \mathrm{C}$ for incubations and analyses. The sterile sulfidic seawater in the gastight jars were refreshed periodically during storage at $4^{\circ} \mathrm{C}$. The majority of the rate experiments $(80 \%)$ were set up immediately on the ship using freshly collected samples. In parallel, subsamples $\left(\sim 1 \mathrm{~cm}^{3}\right)$ from each flange were preserved aboard ship in glutaraldehyde $(2.5 \%$ in phosphate buffered saline, PBS, $\mathrm{pH} 7.0$ ), then prepared for electron microscopy via ethanol dehydration and critical point drying before being sputtered with a thin layer of gold-palladium to improve image resolution. Samples were imaged with a Zeiss model EVO Scanning Electron Microscope (SEM).

\section{Measuring Sulfate Reduction Rates Experimental Design and Incubation}

Prior to incubation, each flange subsample was pulverized by hand for about $1 \mathrm{~h}$ to minimize fine-scale geological and microbial heterogeneity and facilitate more accurate experimental replication (akin to slurry experiments in sediments; Fossing and Jørgensen, 1989; Jørgensen et al., 1992; Weber and Jørgensen, 2002). Specifically, each subsample was pulverized with a flame-sterilized sledgehammer in sterile seawater actively bubbled with nitrogen within an anaerobic chamber. For each independent treatment, aliquots of $7.5 \mathrm{~mL}$ flange slurry ( $\sim 29 \mathrm{~g}$ wet weight and $20 \mathrm{~g}$ dry weight) were transferred into Balch tubes in an anaerobic chamber, and supplemented with $15 \mathrm{~mL}$ of sterile artificial seawater media designed to mimic the geochemical conditions within a hydrothermal flange $\left(400 \mathrm{mM} \mathrm{NaCl}, 25 \mathrm{mM} \mathrm{KCl}, 30 \mathrm{mM} \mathrm{CaCl}_{2}\right.$, $2.3 \mathrm{mM} \mathrm{NaHCO}_{3}, 14 \mathrm{mM} \mathrm{NaSO}_{4}^{2-}, 1 \mathrm{mM} \mathrm{H} \mathrm{H}_{2} \mathrm{~S}$, and $50 \mu \mathrm{M}$ dissolved organic carbon-consisting of equimolar proportions $10 \mu \mathrm{M}$ of pyruvate, citrate, formate, acetate, lactate) under a pure nitrogen headspace.

Concentrations of sulfide, sulfate and dissolved organic carbon (DOC) were varied independently to investigate concentration dependent effects on the rates of SR. The range of experimental conditions tested was determined from previously published concentration profiles of aqueous species modeled as functions of temperature and position within the Grotto vent structure (Tivey, 2004). Concentrations were varied by orders of magnitude within the modeled ranges to simulate conditions representative of different mixing regimes between seawater and vent fluid (Table 1). The range of DOC (which we approximate as a mix of pyruvate, citrate, formate, acetate, lactate-most of which have been identified to varying degrees within vent fluid and are known carbon sources for heterotrophic SR in culture) concentrations tested were based on the average DOC concentrations measured within diffuse fluids at the Main Endeavor Field (Lang et al., 2006, 2010). Hydrogen sulfide was present as $\mathrm{H}_{2} \mathrm{~S}$ ( $\mathrm{pK}_{\mathrm{a}}$ in seawater of 6.60) across all the conditions tested (Amend and Shock, 2001). Incubations were carried out at

TABLE 1 | Experimental media conditions.

\begin{tabular}{|c|c|c|c|c|c|c|}
\hline Experiment & {$\left[\mathrm{H}_{2} \mathrm{~S}\right]$} & [Sulfate] & [DOC] $^{\mathrm{a}}$ & $\mathrm{pH}^{\mathrm{b}}$ & $\begin{array}{c}\text { Temperature } \\
{ }^{\circ} \mathbf{C}\end{array}$ & Innoculum ${ }^{c}$ \\
\hline \multirow[t]{4}{*}{$\Delta$ [Sulfide] } & $0 \mathrm{mM}$ & $14 \mathrm{mM}$ & $50 \mu \mathrm{M}$ & 4,6 & $4,50,90$ & Fresh \\
\hline & $10 \mu \mathrm{M}$ & 14 mM & $50 \mu \mathrm{M}$ & 4,6 & $4,50,90$ & Fresh \\
\hline & $100 \mu \mathrm{M}$ & $14 \mathrm{mM}$ & $50 \mu \mathrm{M}$ & 4,6 & $4,50,90$ & Fresh \\
\hline & $1 \mathrm{mM}$ & $14 \mathrm{mM}$ & $50 \mu \mathrm{M}$ & 4,6 & $4,50,90$ & Fresh \\
\hline \multirow[t]{4}{*}{$\Delta[\mathrm{DOC}]$} & $1 \mathrm{mM}$ & $14 \mathrm{mM}$ & $0 \mu \mathrm{M}$ & 4,6 & $4,50,90$ & Stored \\
\hline & $1 \mathrm{mM}$ & $14 \mathrm{mM}$ & $0.5 \mu \mathrm{M}$ & 4,6 & $4,50,90$ & Stored \\
\hline & $1 \mathrm{mM}$ & 14 mM & $5 \mu \mathrm{M}$ & 4,6 & $4,50,90$ & Stored \\
\hline & $1 \mathrm{mM}$ & 14 mM & $50 \mu \mathrm{M}$ & 4,6 & $4,50,90$ & Stored \\
\hline \multirow[t]{5}{*}{$\Delta$ [Sulfate] } & $1 \mathrm{mM}$ & $10 \mathrm{nM}$ & $50 \mu \mathrm{M}$ & 4,6 & 50 & Stored \\
\hline & $1 \mathrm{mM}$ & $1 \mu \mathrm{M}$ & $50 \mu \mathrm{M}$ & 4,6 & 50 & Stored \\
\hline & $1 \mathrm{mM}$ & $10 \mu \mathrm{M}$ & $50 \mu \mathrm{M}$ & 4,6 & 50 & Stored \\
\hline & $1 \mathrm{mM}$ & $100 \mu \mathrm{M}$ & $50 \mu \mathrm{M}$ & 4,6 & 50 & Stored \\
\hline & $1 \mathrm{mM}$ & $1 \mathrm{mM}$ & $50 \mu \mathrm{M}$ & 4,6 & 50 & Stored \\
\hline
\end{tabular}

The base for each experiment was artificial seawater mix ( $\mathrm{KCl}, \mathrm{CaCl}, \mathrm{NaCl})$ and $2.3 \mathrm{mM}$ bicarbonate.

${ }^{a}$ Dissolved organic carbon amendments consisted of equimolar proportions of pyruvate, citrate, formate, acetate, and lactate. ${ }^{b} \mathrm{pH}$ of media added to incubations.

${ }^{c}$ Homogenized hydrothermal flange used fresh (i.e., immediately after collection on the boat), or stored (used within 1 year of collection, storage in anaerobic sulfidic seawater at $4^{\circ} \mathrm{C}$. SR rates measured 1 year after collection (stored) were not statistically different from sulfate reduction measurements made immediately after collection fresh). 
$\mathrm{pH} 4$ (to simulate the $\mathrm{pH}$ of end-member Grotto vent fluid and the average calculated $\mathrm{pH}$ of mixed fluids in highly reduced zones within the flange; Tivey, 2004) as well as pH 6 (representative of the calculated $\mathrm{pH}$ in fluid mixing zones; Tivey, 2004). All the results are presented and discussed in the context of the initial measured media conditions. During incubation, it is plausible that the dissolution or precipitation of sulfide minerals (or other chemical reactions) may have affected the $\mathrm{pH}$ and chemical composition of the media. Due to the presence of the radioactive tracer, fluid $\mathrm{pH}$ could not be readily measured throughout the course of the experiment. Estimates of final fluid conditions calculated with EQ3/6 support the observation that changes in fluid composition are likely consistent across samples incubated under the same conditions.

Sufficient ${ }^{35} \mathrm{SO}_{4}^{2-}$ was added to achieve $15 \mu \mathrm{Ci}$ of activity. Samples were incubated anaerobically for 1, 3, or 7 days at ambient seawater $\left(4^{\circ} \mathrm{C}\right)$, thermophilic $\left(50^{\circ} \mathrm{C}\right)$, and hyperthermophilic $\left(90^{\circ} \mathrm{C}\right)$ temperatures. The range of temperatures considered was representative of different thermal regimes associated with the surface, outer layer and middle regions of hydrothermal chimneys (Schrenk et al., 2003; Tivey, 2004; Kormas et al., 2006). Negative controls consisted of samples amended with $28 \mathrm{mM}$ molybdate to inhibit SR (Saleh et al., 1964; Newport and Nedwell, 1988). Three biological replicates were run for each treatment, and two biological replicates for each control.

Upon completion, reactions were quenched with the injection of $5 \mathrm{~mL} \mathrm{25 \%}$ zinc acetate, at pH 8 (i.e., 20-fold excess $\mathrm{Zn}$ ), and all samples were frozen at $-20^{\circ} \mathrm{C}$ for further analysis. Eighty percent of incubations were performed shipboard with freshly collected samples and the remaining $20 \%$ of incubations were completed within 1 year of collection. Select incubations performed on ship and replicated in the laboratory within 1 year of collection revealed no significant shift in observed SR rates due to the storage conditions (see Figure 3). However, even though the rates seemed unaffected, we have no data on the taxonomic composition of the sulfate reducing communities and cannot exclude the possibility that communities may have shifted during storage as has been shown to be the case for stored sediment cores (Lin et al., 2010).

\section{Chromium Distillation Analysis}

To determine SR rates, samples were thawed and the supernatant was removed and filtered through a $0.2 \mu \mathrm{m}$ syringe filter. The homogenized flange that remained in the tube was washed three times with deionized water to remove any remaining sulfate. One gram (wet weight) of flange material was added to $10 \mathrm{~mL}$ of a $1: 1$ ethanol to water solution in the chromium distillation apparatus, and then degassed with nitrogen for 15 min to drive the environment anoxic. Hydrogen sulfide gas was evolved after the anaerobic addition of $8 \mathrm{~mL}$ of $12 \mathrm{~N}$ $\mathrm{HCl}$ and $10 \mathrm{~mL}$ of $1 \mathrm{M}$ reduced chromium chloride, followed by $3 \mathrm{~h}$ of heating. The resulting hydrogen sulfide gas was carried via nitrogen gas through a condenser to remove $\mathrm{HCl}$, and was then trapped as zinc sulfide in a $25 \%$ zinc acetate solution. While cold distillation methods for measuring SR using radiotracers have been developed and improved in recent years
(Kallmeyer et al., 2004a; Røy et al., 2014), our experience has shown that-for metal-rich sulfide deposits-the hot chromium distillation method is sufficient in producing consistent results when run with the appropriate controls. To moderate potential artifacts of hot distillation methods including elevated rates in control samples, experiments were analyzed in triplicate, on different days and with different glassware to minimize cross-contamination, and any activity observed in "control" samples was deleted from the treatments. The radioactivity of the resulting sulfide $\left(\mathrm{Zn}^{35} \mathrm{~S}\right)$ and the remaining sulfate from the supernatant $\left({ }^{35} \mathrm{SO}_{4}^{2-}\right)$ were measured via liquid scintillation counter in Ultima Gold scintillation cocktail (ThermoFisher Inc., Waltham, MA).

\section{Calculating Sulfate Reduction Rates}

Rates were determined using the following calculation as in Fossing and Jørgensen (1989).

$$
S R R=\frac{\mathrm{nSO}_{4}^{2-} \cdot a \cdot 1.06}{(a+A) \cdot t}
$$

Where $\mathrm{nSO}_{4}^{2-}$ is the quantity (in moles) of sulfate added to each incubation $\left(14 \mathrm{mM}^{*} 15 \mathrm{~mL}=210 \mu \mathrm{mol}\right), a$ is the activity $(\mathrm{dpm})$ of the trapped sulfide, 1.06 is the fractionation factor between the hydrogen sulfide and sulfate pools (Jørgensen and Fenchel, 1974), $A$ is the activity of the sulfate pool at the completion of the incubation and $t$ is the incubation time (days). The rates are presented in units of nmol S g $\mathrm{g}^{-1} \mathrm{day}^{-1}$. As previously mentioned, SR rates are numerically presented as the difference in rates between experimental and the molybdate inhibited controls, further mitigating any potential artifacts caused by hot distillation methods.

\section{Calculating $\boldsymbol{V}_{\max }, \boldsymbol{K}_{\boldsymbol{m}}$, and Assumptions}

The Michaelis-Menten kinetic parameters of maximum rate $\left(\mathrm{V}_{\max }\right)$ and half-saturation constant $\left(K_{m}\right)$ were determined using a linearization of SR rate $(V)$ vs. sulfate concentration $[S]$ data via the Hanes Woolf plot (Equation 2),

$$
\frac{[S]}{V}=\frac{V_{\max }[S]}{K_{m}+[S]}
$$

which is more accurate than the double reciprocal LineweaverBurk plot (Leskovac, 2003). The slope and X-intercept of the Hanes Woolf plot yield $\frac{1}{V_{\max }}$ and $K_{m}$ respectively. Sulfate concentrations plotted were initial concentrations as has been historically used when incubation conditions were short and sulfate concentrations were not depleted such that they significantly influenced SR rates (Pallud and Van Cappellen, 2006). Based on our previous study (Frank et al., 2013), we anticipated that the magnitude of SR rates would be on the order of $n m o l g^{-1}$ day $^{-1}$. Given that the input sulfate concentrations range from $\mu \mathrm{M}$ to $\mathrm{mM}$ - three orders of magnitude greater than the rate of consumption-and changes in sulfate concentration could not be resolved with our methods, the maximum input of SR activity on the concentration of sulfate is $0.03 \%$. Consequently, we use the initial concentration here without concern. 


\section{Bioenergetic Calculations}

Potential energy yields of the different metabolisms available in the incubations depend on temperature and fluid compositions. To quantify the energy yield from heterotrophic sulfate reduction (Table 2) in each incubation values of overall Gibbs energy $\left(\Delta G_{r}\right)$ were calculated according to:

$$
\Delta G_{r}=\Delta G_{r}^{0}+\mathrm{RT} \ln \mathrm{Q}
$$

where $\Delta G_{r}^{0}$ is the standard Gibbs energy of reaction at in situ temperature and pressure conditions, $\mathrm{R}$ is the gas constant, $\mathrm{T}$ is the temperature (Kelvin), and Q is the activity product, defined as

$$
Q=\Pi a_{i}^{v i}
$$

where $a_{i}$ represents the activity of the $i$ th species and $v_{i}$ is the stoichiometric reaction coefficient, which is positive for products and negative for reactants. Values of $\Delta G_{r}^{0}$ were calculated at 1 bar and incubation temperatures using the geochemical software package SUPCRT92 (Johnson et al., 1992) and additional thermodynamic data from Shock (1995). Activities of aqueous species were calculated using the geochemical speciation program EQ3 (Wolery, 1992a) based on the media composition described in Section Measuring Sulfate Reduction Rates and Table 1, with additional data from previously published work (Shock and Koretsky, 1993; Shock, 1995). For concentrations equal to zero, a value of $10^{-13} \mathrm{~mol} / \mathrm{kg}$ was used as input. Resulting aqueous activities were used to calculate values of $\Delta G_{r}$ normalized for the number of electrons transferred in the redox for the reactions in Table 2. These reflect the metabolic energy available at the start of each incubation experiment for the complete oxidation of each organic acid, metabolisms that are documented among known sulfate reducers (Amend and Shock, 2001). Furthermore, to calculate the energy density in each incubation (as in Amend et al., 2011), it was assumed that the amended organic acids were the limiting reactant for all experiments when sulfate concentrations were in excess of $1 \mathrm{mM}$; otherwise sulfate was assumed to be limiting. While some sulfate reducers are known to produce carboxylic acid and alcohol intermediates, incomplete oxidation reactions were not considered here, as the goal of these calculations was to generate a broad understanding of sulfate reduction energetics, and not the metabolic potential for a particular species. Such an approach is common when comparing microbial metabolisms independent of species-specific pathways (e.g., Amend et al., 2004; Rogers and Amend, 2006; Skoog et al., 2007), although it should be noted that incomplete oxidation (fermentation) generally yields much less energy than complete oxidation (Rogers and Amend, 2006; Skoog et al., 2007).

To account for potential interactions between chimneyderived trace metals and amended sulfide, the saturation states of sulfide minerals were calculated as part of the initial fluid speciation (see above). Using reported concentrations of relevant trace metals ( $\mathrm{Fe}, \mathrm{Zn}, \mathrm{Cu}$, etc.) in end-member Grotto hydrothermal fluid (Butterfield et al., 1994), maximum aqueous activities of trace metals were calculated with the EQ3 geochemical speciation program (Wolery, 1992a,b). Several sulfide minerals commonly found in hydrothermal chimneys (e.g., pyrite, chalcocite, sphalerite) were supersaturated under incubation conditions, particularly for incubations with high concentrations of amended sulfide. The irreversible abiotic precipitation of mineral sulfides has the potential to draw down aqueous sulfide concentrations and impact sulfate reductions rates. Therefore, the geochemical reaction path program EQ6 (Wolery, 1992a; Wolery and Daveler, 1992) was used to constrain fluid compositions to equilibrium with these minerals phases. Using the single point model in EQ6, the Gibbs energy of the system was allowed to reach local minima by mineral precipitation, however redox reactions among carbon and sulfur species was suppressed with a custom thermodynamic database. The resulting fluid compositions were used to calculate metabolic reaction energetics as well as to evaluate the potential effects of metal speciation on sulfate reduction rates.

\section{RESULTS}

\section{Physical Characteristics of the Study Site and Microscopy}

Diffuse hydrothermal flow was observed on the surface of the hydrothermal flange of Grotto ranging in temperature from 2 to $18.1^{\circ} \mathrm{C}$, while hot hydrothermal fluid $\left(T_{\max }=215.6^{\circ} \mathrm{C}\right)$ was observed in pools accumulating on the underside of an overhanging flange. Sulfide minerals nearest to the hottest fluid were relatively friable, whereas the majority of the flange sampled was relatively solid, likely due to the precipitation of pyrrhotite, pyrite, and silica (Tivey and Delaney, 1986) in pore spaces at lower temperatures. An inner conduit-like channel was clearly present in the interior of the flange and densely lined with pyrite. Thick veins of anhydrite and channels of marcasite were also observed throughout the samples. Crystals of these minerals were imaged using scanning electron microscopy. Microbial cells were observed associated with mineral surfaces in low abundance

TABLE 2 | Heterotrophic sulfate reduction.

\begin{tabular}{lll}
\hline Carbon source & Reaction & \\
\hline Formate & $\mathrm{SO}_{4}^{2-}+4 \mathrm{CH}_{2} \mathrm{O}_{2} \rightarrow \mathrm{H}_{2} \mathrm{~S}+4 \mathrm{HCO}_{3}^{-}+2 \mathrm{H}^{+}$ & 8 \\
Acetate & $\mathrm{SO}_{4}^{2-}+\mathrm{C}_{2} \mathrm{H}_{4} \mathrm{O}_{2} \rightarrow \mathrm{H}_{2} \mathrm{~S}+2 \mathrm{HCO}_{3}^{-}$ & 8 \\
Pyruvate & $5 \mathrm{SO}_{4}^{2-}+4 \mathrm{C}_{3} \mathrm{H}_{4} \mathrm{O}_{3}+4 \mathrm{H}_{2} \mathrm{O} \rightarrow 5 \mathrm{H}_{2} \mathrm{~S}+12 \mathrm{HCO}_{3}^{-}+2 \mathrm{H}^{+}$ & 40 \\
Lactate & $3 \mathrm{SO}_{4}^{2-}+2 \mathrm{C}_{3} \mathrm{H}_{6} \mathrm{O}_{3} \rightarrow 3 \mathrm{H}_{2} \mathrm{~S}+6 \mathrm{HCO}_{3}^{-}$ & 24 \\
Citrate & $9 \mathrm{SO}_{4}^{2-}+4 \mathrm{C}_{6} \mathrm{H}_{5} \mathrm{O}_{7}^{3-}+8 \mathrm{H}_{2} \mathrm{O}+6 \mathrm{H}^{+} \rightarrow 9 \mathrm{H}_{2} \mathrm{~S}+24 \mathrm{HCO}_{3}^{-}$ & 72
\end{tabular}


(Figure S1). There was no visual evidence of dense biofilms within the sample.

\section{Sulfate Reduction Rates}

Sulfate reduction was detected in incubations of flange material recovered from the Grotto vent at 4, 50, and $90^{\circ} \mathrm{C}$ over a range of environmentally-relevant chemical conditions $(\mathrm{pH}$, $\mathrm{H}_{2} \mathrm{~S}, \mathrm{SO}_{4}^{2-}$, and organic carbon concentrations). Measured rates (except for those at low sulfate concentrations) are comparable in magnitude to those previously observed in hydrothermallyinfluenced sediments (e.g., Guaymas Basin or Lake Tanganyika; Elsgaard et al., 1994a,b; Weber and Jørgensen, 2002; Kallmeyer and Boetius, 2004). Among all treatments, the highest observed rate $\left(3940 \mathrm{nmol} \mathrm{g}^{-1} \mathrm{day}^{-1}\right)$ occurred at $100 \mu \mathrm{M} \mathrm{H}_{2} \mathrm{~S}, 14 \mathrm{mM}$ $\mathrm{SO}_{4}^{2-}, 50 \mu \mathrm{M}$ DOC, $\mathrm{pH} 6$, and $50^{\circ} \mathrm{C}$. The lowest observed rates $\left(120 \mathrm{fmol} \mathrm{g}^{-1} \mathrm{day}^{-1}-1.5 \mathrm{nmol} \mathrm{g}^{-1}\right.$ day $\left.^{-1}\right)$ were under conditions of most pronounced sulfate limitation $(10-100 \mu \mathrm{M})$ in the presence of $1 \mathrm{mM} \mathrm{H}_{2} \mathrm{~S}$, at pH 4 and 6 , and at $50^{\circ} \mathrm{C}$ (it should be noted that we did not conduct these same sulfate limitation experiments at 4 and $90^{\circ} \mathrm{C}$ ).

Control experiments were designed to inhibit biological sulfate reduction through the use of molybdate, a known inhibitor of SR. The SR rates in these controls were much lower than experimental samples (Mann-Whitney-Wilcox test, $p=$ 0.1 ), though none of the samples were entirely inhibited, which is likely the result of mineral scavenging of molybdate (Bostick et al., 2003; Xu et al., 2006) or as an artifact of hot chromium distillation methods (Kallmeyer et al., 2004b). While we present rates for both experimental and molybdate-amended samples to provide a perspective on the relative contributions of abiotic vs. biotic sulfate reduction under varying environmental conditions (Figures 2-4), the subsequent analyses focus on a conservative measure of net biological rates, namely the difference in rates between experimental and the molybdate-inhibited controls. Additionally, because rates from 3-day to 7-day incubations were not significantly different from one another in these treatments ( $n=271$; Mann-Whitney-Wilcoxon, $p=0.728$ ), they are being treated as pseudo-replicates. As has been previously observed (Frank et al., 2013), SR rates exhibited large standard deviations, presumably due to microscale sample heterogeneity (despite efforts to homogenize, mineral clasts ranged in size from 0.003 to $80 \mathrm{~mm}^{3}$ ) among biological replicates. Such variation is consistent with the patterns we observed in previous SR rate measurements on Middle Valley vent deposits (with mineral sizes $0.001-7 \mathrm{~mm}^{3}$; Frank et al., 2013).

The highest SR rates across all conditions tested were observed at $50^{\circ} \mathrm{C}$ (Figure 1). The average SR rates with $14 \mathrm{mM}$ sulfate were $16.4 \mathrm{nmol} \mathrm{g}^{-1} \mathrm{day}^{-1}$ at $4^{\circ} \mathrm{C}\left(3.99-66.8 \mathrm{nmol} \mathrm{g}^{-1} \mathrm{day}^{-1}\right)$, $270 \mathrm{nmol} \mathrm{g}{ }^{-1} \mathrm{day}^{-1}$ at $50^{\circ} \mathrm{C}\left(10.0-1690 \mathrm{nmol} \mathrm{g}^{-1}\right.$ day $\left.^{-1}\right)$, and $7.66 \mathrm{nmol} \mathrm{g}^{-1} \mathrm{day}^{-1}$ at $90^{\circ} \mathrm{C}\left(0-24.9 \mathrm{nmol} \mathrm{g}^{-1}\right.$ day $^{-1}$ at $\left.90^{\circ} \mathrm{C}\right)$. SR rates observed at $50^{\circ} \mathrm{C}$ were significantly higher than those measured at $4^{\circ} \mathrm{C}(n=152$; Mann-Whitney-Wilcoxon, $p<0.0001)$ and $90^{\circ} \mathrm{C}(n=151$; Mann-Whitney-Wilcoxon, $p<0.0001)$. Notably, $60 \%$ of samples incubated at $90^{\circ} \mathrm{C}$ show no biological sulfate reduction. Our data show that when temperature is varied independently from chemistry (under thermodynamically favorable conditions of excess sulfate and no

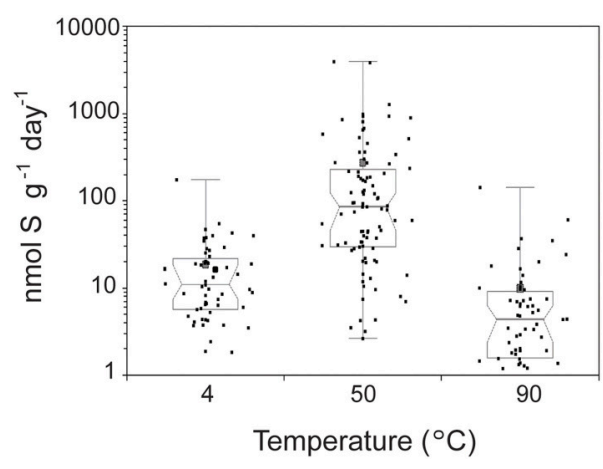

FIGURE 1 | Temperature dependence of sulfate reduction rates in crushed hydrothermal flange from Grotto vent (Main Endeavor, JdF).

The median of 213 samples is plotted as a line, the 1st and 3rd quartiles as a box, and the minimum and maximum as whiskers with end caps. The 95\% confidence interval of the median is represented by a notch on the box. The mean of the 213 samples is depicted as a gray square. Black squares indicate individual measurements. Note rates measured from sulfate gradient experiments were excluded in this figure because those experiments were only done at $50^{\circ} \mathrm{C}$.

oxygen), the highest rates of SR occur at $50^{\circ} \mathrm{C}$. Furthermore, the distribution of rates with respect to temperature resembles distributions observed in hydrothermal sediments (Jørgensen et al., 1992; Elsgaard et al., 1994a; Weber and Jørgensen, 2002) and basaltic crustal fluids (Robador et al., 2015), where optimal temperatures range between 40 and $80^{\circ} \mathrm{C}$, but it differs from those measured in vent structures from Middle Valley, where maximal rates were observed at $90^{\circ} \mathrm{C}$ (Frank et al., 2013).

SR rates observed at $\mathrm{pH} 6$ were significantly higher than those measured at $\mathrm{pH} 4(n=271$; Mann-Whitney-Wilcoxon, $p=0.0267)$. The average SR rates at $\mathrm{pH} 6$ were $149 \mathrm{nmol}$ $\mathrm{g}^{-1}$ day $^{-1}$ compared to $35.6 \mathrm{nmol} \mathrm{g}^{-1}$ day $^{-1}$ at $\mathrm{pH} 4$. Maximum SR rates at $\mathrm{pH} 6$ seem incongruous with the $\mathrm{pH}$ of endmember hydrothermal fluid (4.2-4.7; Butterfield et al., 1994; Tivey, 2004), particularly in light of observations of Lake Tanganyika hydrothermal sediments, where maximum SR rates were observed at $\mathrm{pH}$ conditions near hydrothermal vent values (Elsgaard et al., 1994b). However, mixing models by Tivey (2004) predict fluid compositions with a $\mathrm{pH}$ of $\sim 6$ at $50^{\circ} \mathrm{C}$ when mixing is driven by seawater advection, suggesting that microbial communities adapted to the $50^{\circ} \mathrm{C}$ niche in the Grotto flange also have an optimal $\mathrm{pH}$ range close to estimated in situ values.

While temperature and $\mathrm{pH}$ were the dominant factors influencing SR rates, media amendments were also correlated with rates, though to a lesser degree. SR rates were positively correlated $(p<0.0001)$ with sulfate concentration $(10-14 \mathrm{mM})$ at both $\mathrm{pH} 6$ and $\mathrm{pH} 4$ (Figure 2). Over the entire range of sulfate concentrations tested (seven orders of magnitude), SR rates ranged from $50.1 \mathrm{fmol} \mathrm{g}^{-1}$ day $^{-1}$ to $930 \mathrm{nmol} \mathrm{g}^{-1}$ day $^{-1}$ at pH 6 (seven orders of magnitude) and from $9.8 \mathrm{fmol} \mathrm{g}^{-1}$ day $^{-1}$ to $805 \mathrm{nmol} \mathrm{g}^{-1} \mathrm{day}^{-1}$ at $\mathrm{pH} 4$ (eight orders of magnitude). Furthermore, SR rates were slightly higher at $\mathrm{pH} 4$ when sulfate concentrations were less than $14 \mathrm{mM}$. Michaelis-Menten Kinetics parameters determined using the Hanes-Woolf linearized form 


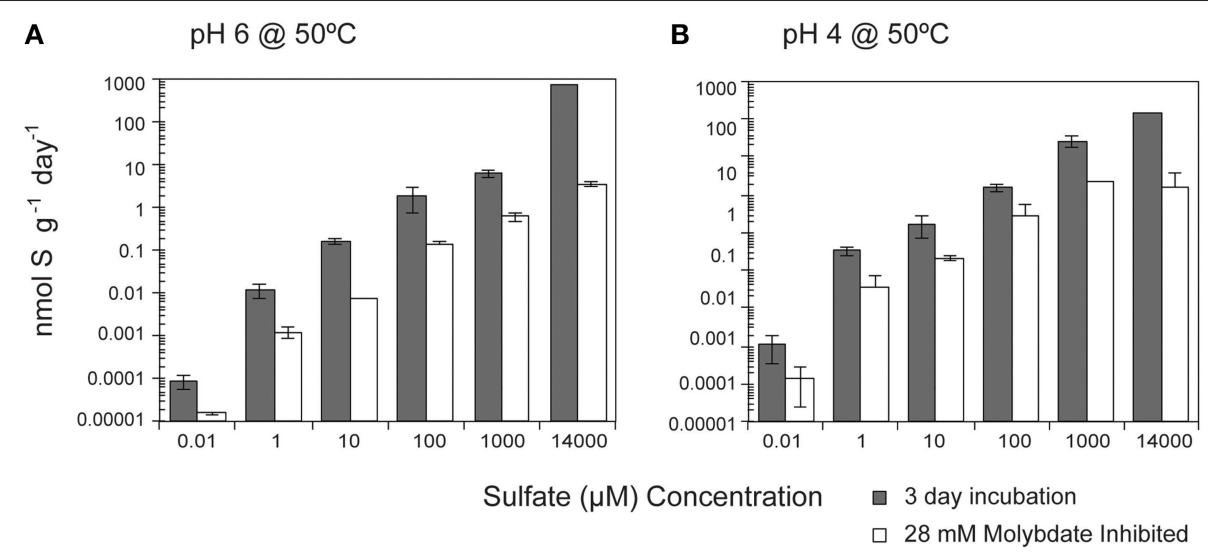

FIGURE 2 | Effect of sulfate concentration on sulfate reduction rates. The crushed flange from the Grotto hydrothermal deposits were incubated for 3 days ( at $50^{\circ} \mathrm{C}$ at $\mathbf{( A )} \mathrm{pH} 6$ or $\mathbf{( B )} \mathrm{pH} 4.28 \mathrm{mM}$ molybdate amended samples were incubated under all conditions ( $\square$ ) as controls. Error bars represent 1 standard deviation.
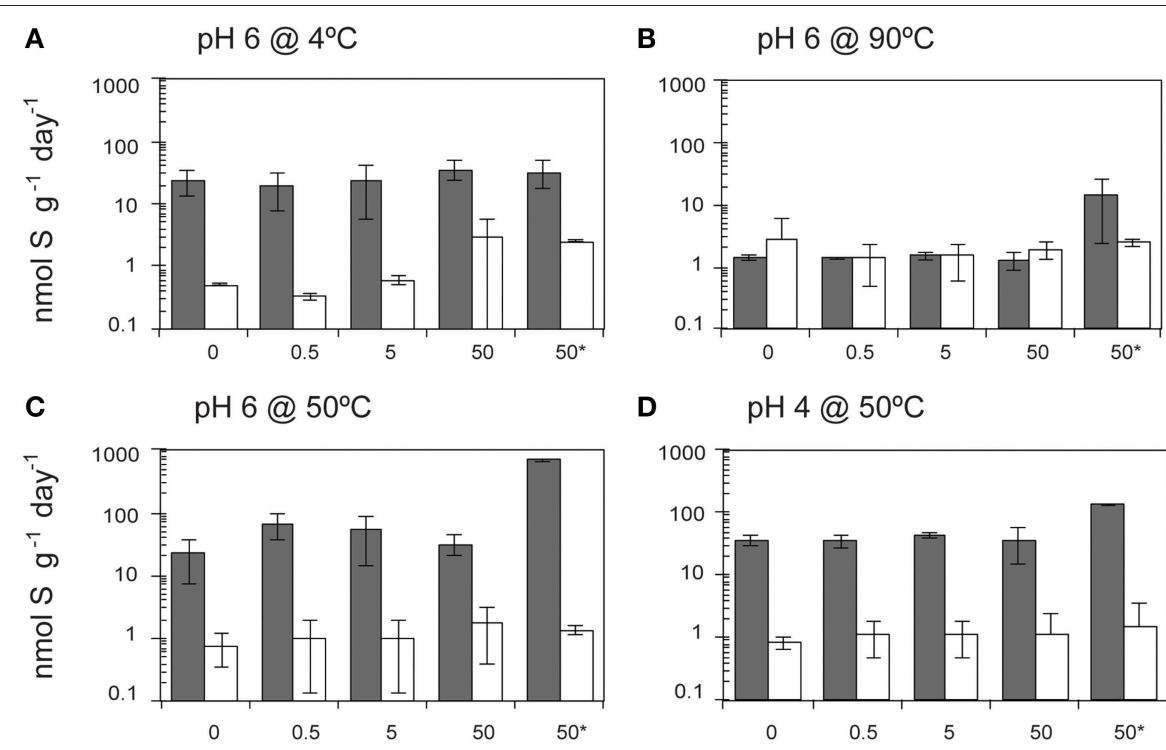

D $\quad \mathrm{pH} 4 @ 50^{\circ} \mathrm{C}$

FIGURE 3 | Effect of dissolved organic carbon (DOC) concentrations on sulfate reduction rates. The crushed flange from the Grotto hydrothermal deposits were incubated for 3 days $(\square)$ in media of $(\mathbf{A}) \mathrm{pH} 6$ at $4^{\circ} \mathrm{C}$, (B) $\mathrm{pH} 6$ at $90^{\circ} \mathrm{C}$, (C) pH 6 at $50^{\circ} \mathrm{C}$, and (D) pH 4 at $50^{\circ} \mathrm{C}$. While most of experiments were performed in laboratory using stored samples, concentrations identified with an asterisk $\left(^{*}\right)$ were done shipboard immediately after collection of hydrothermal chimney. $28 \mathrm{mM}$ molybdate amended samples were incubated under all conditions ( $\square$ ) as controls. Error bars represent 1 standard deviation. Note the log scale on the $y$-axis.

of the Michaelis-Menten rate equation (Equation 2) revealed a $K_{m}$ value of $7.1 \mathrm{mM}$ and $V_{\max }$ of $298 \mathrm{nmol} \mathrm{g}^{-1}$ day $^{-1}$ for SR at pH $6\left(r^{2}=0.441\right)$ and a $K_{m}$ value of $2.5 \mathrm{mM}$ and $\mathrm{V}_{\max }$ of $298 \mathrm{nmol} \mathrm{g}^{-1}$ day $^{-1}$ at $\mathrm{pH} 4\left(r^{2}=0.513\right) . K_{m}$, defined as the sulfate concentration at which SR rates are half-maximum, is a measure of affinity for sulfate (higher $K_{m}$ corresponds to lower affinity). Given that the $K_{m}$ values for most enzymes in the sulfate reduction pathways range roughly from 5 to $100 \mu \mathrm{M}$ in cultured organisms (Trüper and Rogers, 1971; Ingvorsen et al., 1981; Ingvorsen and Jørgensen, 1984; Sonne-hansen and Westermann,
1999; Ramos et al., 2012), the pattern of SR rates observed in these experiments suggests that sulfate reduction enzymes do not reach saturation at the amended sulfate concentrations (plausible explanations for this observation are presented in the discussion). The apparent $K_{m}$ value for SR at pH 6 is higher than the highest reported $K_{m}$ values for thermophilic SR (3.17 \pm $1.02 \mathrm{mM}$ ) from Yellowstone Mushroom Springs (Roychoudhury, 2004). Interestingly, the apparent $K_{m}$ values for SR at pH 6 are higher than at $\mathrm{pH} 4$, even though $V_{\max }$ remains constant under both conditions. Due to the low $r^{2}$ values for linear regressions, 

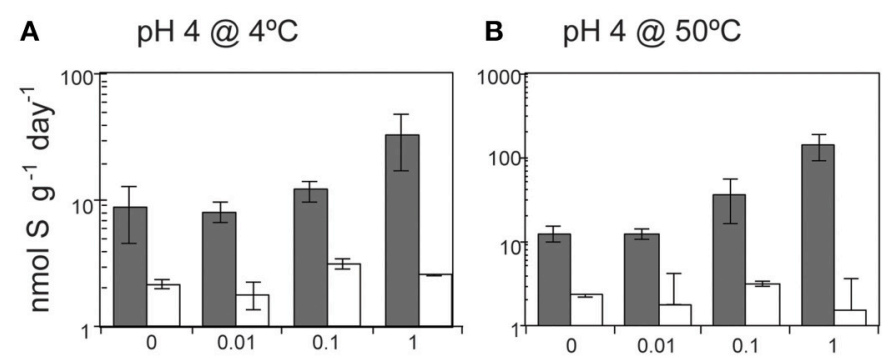

C $\mathrm{pH} 4 @ 90^{\circ} \mathrm{C}$
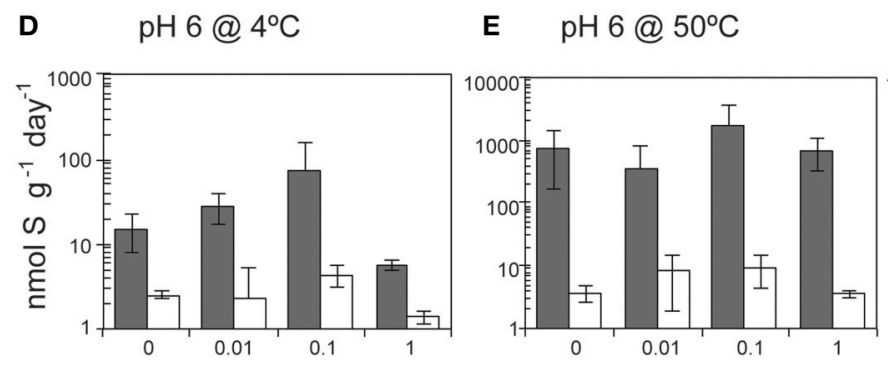

F $\quad \mathrm{pH} 6 @ 90^{\circ} \mathrm{C}$

$\mathrm{H}_{2} \mathrm{~S}(\mathrm{mM})$ Concentration
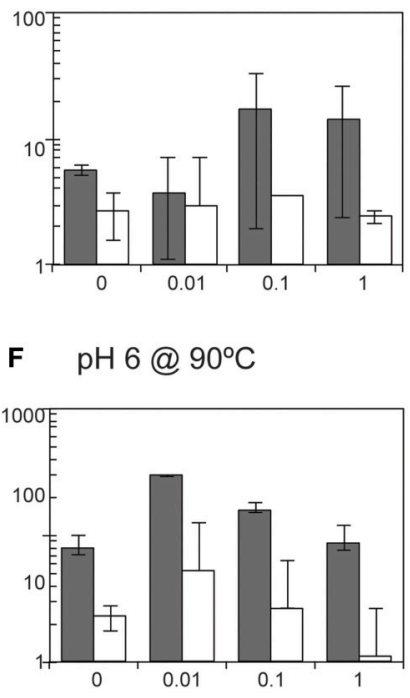

口 3 day incubation

$28 \mathrm{mM}$ Molybdate Inhibited

FIGURE 4 | Effect of sulfide concentration on sulfate reduction rates. The crushed flange from the Grotto hydrothermal deposits were incubated for 3 days in media of (A) pH 4 at $4{ }^{\circ} \mathrm{C}$, (B) pH 4 at $50^{\circ} \mathrm{C}$, (C) pH 4 at $90^{\circ} \mathrm{C}$, (D) $\mathrm{pH} 6$ at $4{ }^{\circ} \mathrm{C},(\mathbf{E}) \mathrm{pH} 6$ at $50^{\circ} \mathrm{C}$, and (F) pH 6 at $90^{\circ} \mathrm{C} .28$ mM molybdate amended samples were incubated under all conditions $(\square)$ as controls. Error bars represent 1 standard deviation. Note different scales for $(\mathbf{A}, \mathbf{C})$.

future experiments should consider a wider range of sulfate concentrations to validate these values.

$\mathrm{SR}$ rates in the treatments without any exogenous DOC amendment were not significantly different from those incubated with DOC (pyruvate, citrate, formate, acetate, and lactate) at concentrations up to $50 \mu \mathrm{M}$ (Pearson's correlation, $p=0.565$; Figure 3). The observed rates suggest that the communities were not carbon limited and could have been utilizing organic carbon associated with flange materials. Given the common occurrence of macrofauna upon these chimneys, it is likely that endogenous organic carbon pools-such as from macrofaunal necromassexist in these systems.

Overall, SR rates (ranging from 1.9 to $3936 \mathrm{nmol} \mathrm{g}^{-1}$ day $^{-1}$ ) were positively correlated with the concentration of hydrogen sulfide (Pearson's correlation, $n=213, p=0.04$; Figure 4). A strong correlation was observed at $\mathrm{pH} 4$ at both $4^{\circ} \mathrm{C}(p<0.0001)$ and $50^{\circ} \mathrm{C}(p<0.0001)$, with SRR rates increasing between one and two orders of magnitude as the sulfide concentration increased from 0 to $1 \mathrm{mM}$ (Table S1). In contrast, SR rates were not significantly correlated with the exogenous sulfide concentration at pH 6 (Pearson's correlation, $p=0.354$ ).

\section{Bioenergetic Models}

The favorability of sulfate reduction in the incubation experiments, as estimated by overall Gibbs energy of reaction, $\Delta G_{r}$, ranged from $-6.41 \mathrm{~kJ} / \mathrm{mol} \mathrm{e}^{-}$to $-20.7 \mathrm{~kJ} / \mathrm{mol} \mathrm{e}^{-}$over the range of sulfate, DOC, and sulfide concentrations tested. Figure 5 shows $\Delta G_{r}$, normalized for the number of electrons transferred, for the range of conditions in the $50^{\circ} \mathrm{C}, \mathrm{pH} 6$ experiments. Note that negative values of $\Delta G_{r}$ indicate exergonic reactions, and higher negative values (increasing on the y-axis) reflect increasing energy levels. While sulfate, DOC, and sulfide concentrations were varied by five orders of magnitude or more, values of $\Delta G_{r}$ only changed by $2-3 \mathrm{~kJ} / \mathrm{mol} \mathrm{e}^{-}$at this temperature and $\mathrm{pH}$, emphasizing that in situ concentrations of individual electron donors, acceptors, or products are not the largest contributor to free energy variations. However, varying the type of electron donor (in this case the species of organic acid) effected changes in $\Delta G_{r}$ up to $\sim 10 \mathrm{~kJ} / \mathrm{mol} \mathrm{e}^{-}$. For example, at $0.1 \mathrm{mM}$ sulfate, oxidation of acetate yields $-7.76 \mathrm{~kJ} / \mathrm{mol} \mathrm{e}^{-}$, while formate oxidation provides up to $-17.79 \mathrm{~kJ} / \mathrm{mol} \mathrm{e}^{-}$. Not surprisingly, the highest calculated energy yields were from formate oxidation under the maximum sulfate and minimum sulfide concentrations (Figure 5Aiii). The effect of temperature on metabolic energy availability was less pronounced than the effect of the organic acid species, with only $1-2 \mathrm{~kJ} / \mathrm{mol} \mathrm{e}^{-}$ variations in $\Delta G_{r}$ for any given reaction evaluated at 4,50 , and $90^{\circ} \mathrm{C}$ (e.g., At $\mathrm{pH} 6,0.1 \mathrm{mM} \mathrm{H}_{2} \mathrm{~S}, 14 \mathrm{mM} \mathrm{SO}_{4}^{2-}$, and $50 \mu \mathrm{M}$ formate, $\Delta G_{r}$ ranged from -18.6 to $-19.3 \mathrm{~kJ} / \mathrm{mol} \mathrm{e}{ }^{-}$from 4 to $\left.90^{\circ} \mathrm{C}\right)$.

In batch experiments, like those described here, overall Gibbs energy values do not represent the amounts of substrate that might be limiting in closed systems. Accounting for the total amount of sulfate and DOC available for each incubation (by multiplying values of $\Delta G_{r}$ in $\mathrm{kJ} / \mathrm{mol} \mathrm{rxn}$, by the concentration and stoichiometric reaction coefficient of the limiting substrate, as well as the volume of the incubation), it is possible to calculate the total amount of energy available (e.g., energy density; LaRowe and Amend, 2015) in each experiment (Figure 5B). Low concentrations of sulfate $\left(\mathrm{SO}_{4}^{2-}\right.$-limited conditions) or 
A Favoribility of $\mathrm{SR}$ at $\mathrm{pH} 6$ and $50^{\circ} \mathrm{C}$
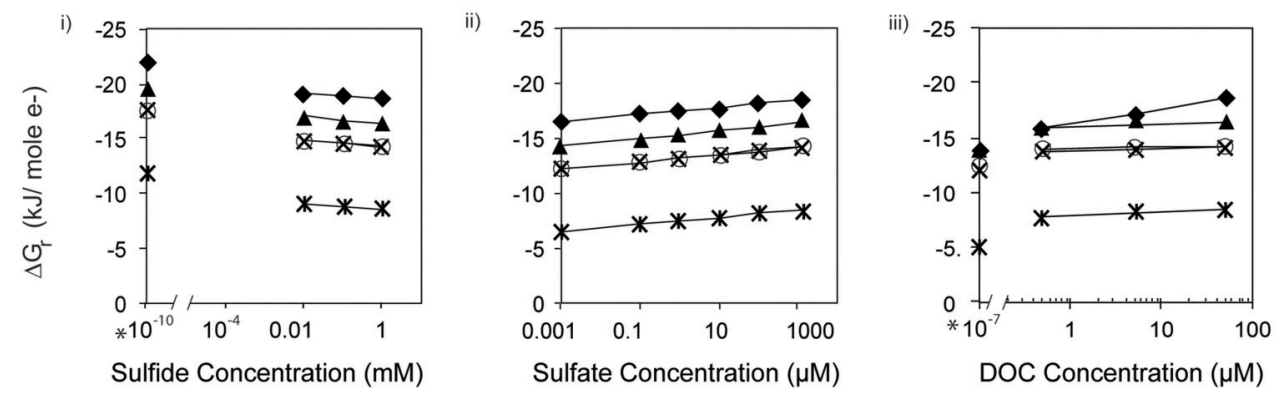

- Formate

A Pyruvate $\bigcirc$ Lactate $\times$ Citrate

* Acetate

B Gibbs Energy Density

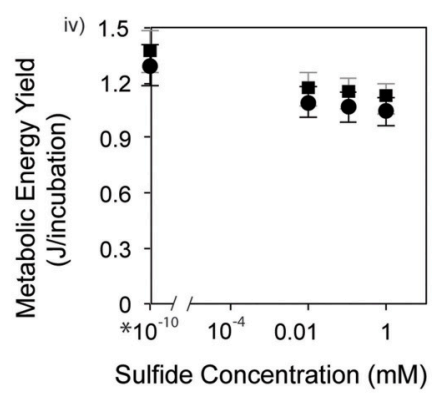

v)

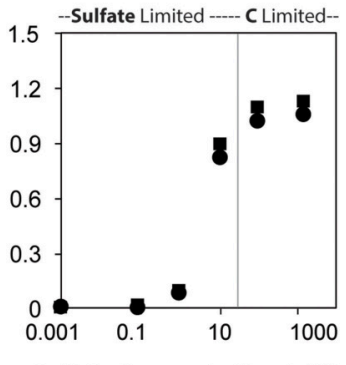

vi)

Sulfate Concentration $(\mu \mathrm{M})$

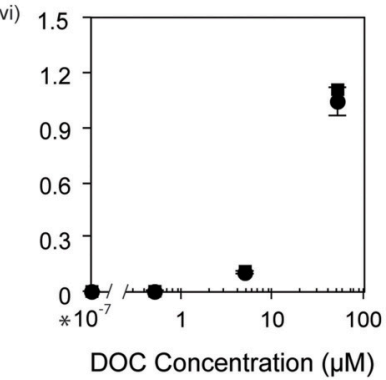

- ph $6 @ 50^{\circ} \mathrm{C}$

- pH $4 @ 50^{\circ} \mathrm{C}$

FIGURE 5 | (A) $\Delta G_{r}\left(\mathrm{~kJ} / \mathrm{mol} \mathrm{e}^{-}\right)$calculated at $\mathrm{pH} 6$ and $50^{\circ} \mathrm{C}$ for heterotrophic sulfate reduction via organic acids (formate, acetate, pyruvate, lactate and citrate) at varying concentrations of (i) sulfide, (ii) sulfate, and (iii) DOC. (B) The total energy available for sulfate reduction in each incubation at $50^{\circ} \mathrm{C}$. Bars on each symbol represent the range of values for $4^{\circ} \mathrm{C}$ and $90^{\circ} \mathrm{C}$. Asterisks $\left(^{*}\right)$ denote contrived values of zero that were inputted into the model for speciation calculation in EQ3.

DOC (organic carbon-limited conditions) both yielded minimal energy density $\left(\sim 10^{-6} \mathrm{~kJ} /\right.$ incubation); however these values rose to nearly $1.2 \mathrm{~kJ} /$ incubation for concentrations of sulfate in excess of $1 \mathrm{mM}$ and DOC at $50 \mu \mathrm{M}$ (all under carbon limitation). Energy densities decreased minimally with increasing sulfide concentrations, consistent with expectations, as metabolic products are not limiting and therefore do not generally affect energy density.

While the species of electron donor, and-to a lesser extentsulfate, sulfide, and individual organic acid concentrations, have some effect on overall metabolic energy yields, our calculations indicate that the largest contributor is the metabolic strategy itself. In general, $\Delta G_{r}$ values for both autotrophic and heterotrophic sulfate reduction occupy a small range of energetics over a broad range of environments compared to other metabolic strategies. For example, Rogers and Amend (2006) found that in situ $\Delta G_{r}$ values for SR coupled to oxidation of carboxylic acids ranged from -6.7 to $-25.99 \mathrm{~kJ} / \mathrm{mol} \mathrm{e}^{-}$ in shallow marine hydrothermal vents, compared to -0.05 to $-122.58 \mathrm{~kJ} / \mathrm{mol} \mathrm{e}^{-}$for all other metabolic strategies considered (Amend et al., 2003; Rogers and Amend, 2006). Energy yields for heterotrophic SR from those shallow marine vents are very similar to values calculated here, despite having higher sulfate concentrations (up to $62 \mathrm{mM}$ ) and orders of magnitude lower sulfide $(<400 \mu \mathrm{M})$ than the Grotto experiments. The metabolic energy yields calculated here are also similar to values predicted from seawater/hydrothermal fluid mixing models (McCollom and Shock, 1997; Rogers and Amend, 2006).

\section{DISCUSSION}

\section{Physiological Constraints on SR Rates}

The magnitude of SR rates within the Grotto flange is primarily governed by the temperature and, to a lesser extent, $\mathrm{pH}$ dependent processes and their effect on the physiology of the native sulfate reducing microbial consortia (Figures 1, 2, 4, 6). As previously noted, the maximum rates of SR occurred at $50^{\circ} \mathrm{C}$ and $\mathrm{pH} 6$, and suggest that the native SR community is most active in a moderate $\left(\sim 50^{\circ} \mathrm{C}\right)$ temperature and only slightly acidic $\mathrm{pH}$ regime. This is consistent with mixing models dominated by seawater advection, where a mixed fluid at $50^{\circ} \mathrm{C}$ had a $\mathrm{pH}$ of $\sim 6$, high sulfate, low sulfide and limited oxygen (note that these calculated concentrations of dissolved $\mathrm{O}_{2}$ do not take into consideration biotic or abiotic reactions that consume oxygen), providing ideal conditions for sulfate reduction in the outer region of the chimney (Tivey, 2004). The correspondence between our maximum SR rates and these mixing models suggests that advection of seawater into the wall of the vent may be an important factor for constraining the physiology of the native sulfate reducing community. 


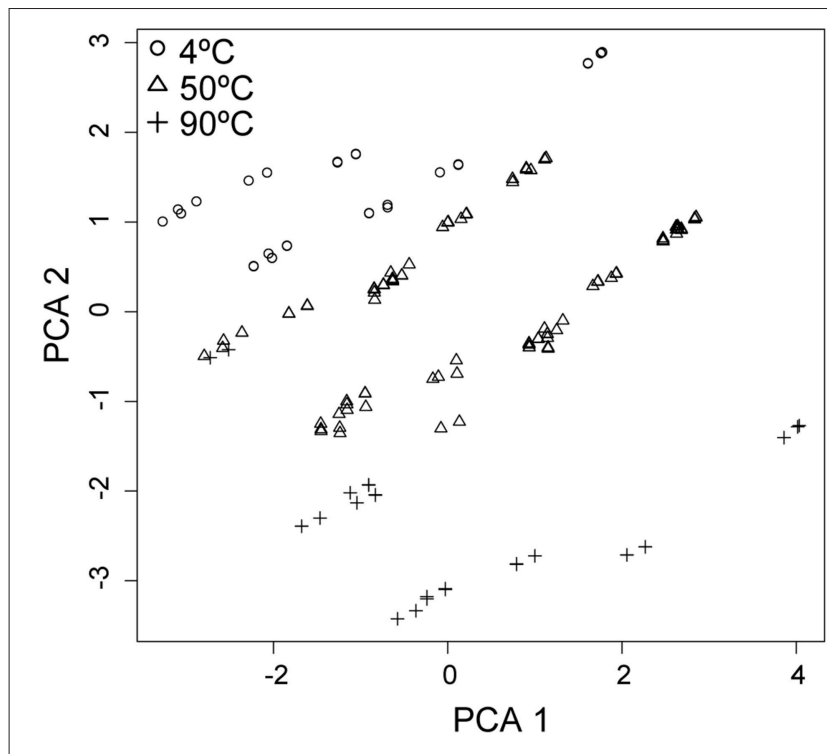

FIGURE 6 | Principal component analysis (PCA) of the variation between samples $(n=274)$ as a linear combination of standardized chemical (sulfate, sulfide, $\mathrm{pH}, \mathrm{DOC}, \mathrm{Cu}^{2+}, \mathrm{Fe}^{2+}$, and $\mathrm{Zn}^{2+}$ ), thermal, rate and energetic parameters (variance within each parameter $=1$ ). PCA 1 represents $28.5 \%$ and PCA 2 represents 19.9\% of the variance within the data (PCA 3 and PCA 4, not shown, represent 12 and $10 \%$ respectively). Data are clustered most obviously by temperature at $4^{\circ} \mathrm{C}(O), 50^{\circ} \mathrm{C}(\Delta)$, and $90^{\circ} \mathrm{C}(+)$.

Previous work in other hydrothermal systems has also suggested that temperature is a primary factor in governing metabolic rates and, likely, community composition. For example, in basalt-hosted borehole fluids from Juan de Fuca Ridge maximum rates of SR occurred at temperatures near in situ conditions and were consistent with physiological tolerances of the native SR community (Robador et al., 2015). Similarly, in hydrothermal chimneys from Middle Valley vent field, Juan de Fuca Ridge, maximum SR rates were observed at temperatures $\left(90^{\circ} \mathrm{C}\right)$ near the growth ranges for the in situ SR community (hyperthermophiles) (Frank et al., 2013). Considering that SR rates from Grotto and Middle Valley were measured under identical experimental conditions, differences in the thermal optima of SR between Grotto and Middle Valley are likely due to differences in the prokaryotic abundance and phylogenetic composition of associated consortia (Frank et al., 2013; Olins et al., 2013). This hypothesis is ecologically consistent with temperature being one of the main driving forces that shape the composition and abundance of hydrothermal vent microbial communities (Harmsen et al., 1997; Takai et al., 2001; Schrenk et al., 2003; Kormas et al., 2006; Pagé et al., 2008). Additionally, differences in density and composition within a chimney are a reflection of the mineralogy and physicochemical conditions at each site. For example, deposits sampled at Middle Valley were physically smaller than Grotto, composed primarily of anhydrite (with no inner conduit like structures), and exposed to higher temperature end-member fluid $\left(261^{\circ} \mathrm{C}\right)$. Thus, it is not surprising that the environment at Middle Valley selected for a hyperthermophilic community dominated by Thermodesulfovibro (Frank et al., 2013) or Archaeoglobuslike (Olins et al., 2013) organisms. On the other hand, Grotto is a very large hydrothermal deposit with a mature mineralogical structure (Tivey and Delaney, 1986), allowing for a greater range of habitable niches and more space for colonization. Because mesophillic, as well as slightly thermophilic phylotypes are often observed to colonize within the outer regions of hydrothermal vents (Takai et al., 2001; Hoek et al., 2003; Schrenk et al., 2003; Nakagawa et al., 2005; Kormas et al., 2006; Pagé et al., 2008), we posit that the majority of SR in the Grotto occurs in the outer to middle region of the flange and is dominated by thermophilic organisms.

\section{Environmental Constraints on SR Rates}

Environmental selection of physiologically adapted microbial communities applies not only to parameters such as temperature and $\mathrm{pH}$, but also to geochemical constraints such as dissolved sulfide and metal toxicity. Some SR isolates can be inhibited by elevated sulfide $(2-15 \mathrm{mM})$ (Reis et al., 1992; Okabe et al., 1995; Koschorreck, 2008), although vent isolates are known to tolerate a wider range of sulfide concentrations. For example, archaea isolated from of deep-sea hydrothermal vents such as Methanocaldococcus jannaschii, Archaeoglobus profundus, Thermococcus fumicolans, and isolates from the genus Pyrococcus and Desulfurococcus have high tolerance to hydrogen sulfide concentrations in the range of 40-100 mM (Jannasch et al., 1988; Lloyd et al., 2005). Our incubations experiments were amended with sulfide at concentrations (up to $1 \mathrm{mM}$ ), well below the values measured in in Grotto end-member fluids $(5.4 \mathrm{mmol} / \mathrm{kg}$ at $\mathrm{pH}=4.2$; Butterfield et al., 1994). Assuming that native Grotto SR communities are adapted to tolerate in situ sulfide concentrations, it is unlikely that sulfide toxicity largely impacted SR rates in our experiments. This is consistent with experiments at optimal temperature and $\mathrm{pH}\left(50^{\circ} \mathrm{C}, \mathrm{pH}\right.$ 6), for which SR rates do not significantly depend on sulfide concentrations (Table S1, $p=0.5$ ), despite the fact that increasing sulfide concentrations do decrease energy yields (Figure 5Aiii).

At $50^{\circ} \mathrm{C}$ and $\mathrm{pH} 4$, measured SR rates increase with increasing sulfide (Figure 4B). The positive correlation of SR with sulfide concentration at $\mathrm{pH} 4$ is surprising given that the favorability $\left(\Delta G_{r}{ }^{\circ}\right)$ of SR decreases with increasing concentrations of sulfide. However, there are no significant correlations between rates of SR and $\Delta G_{r}$ in our sulfide amended incubations (Figure 7A; Pearson's correlation, $p>0.2$ ) and no obvious patterns in energy density that might explain the differences attributable to $\mathrm{pH}$. Accordingly, we investigated the possibility that sulfide amendments were poising the incubations at a redox potential favorable for SR (usually confined to $\mathrm{E}_{\mathrm{h}}$ values of -0.3 to $0.0 \mathrm{~V}$ at circumneutral $\mathrm{pH}$ and slightly more positive under more acidic conditions; Lovley and Goodwin, 1988; Church et al., 2007). While the addition of sulfide at $\mathrm{pH} 4$ does lower the $\mathrm{E}_{\mathrm{h}}$ of the $\mathrm{H}_{2} \mathrm{~S}_{2} \mathrm{SO}_{4}^{2-}$ redox pair, this effect was $\mathrm{pH}$ invariant (Figure $\mathrm{S} 2$ ) and thus we posit that $\mathrm{E}_{\mathrm{h}}$ is unlikely to be the parameter controlling increasing SR rates with increasing sulfide concentrations at $\mathrm{pH}$ 4 and $50^{\circ} \mathrm{C}$.

Fluid $\mathrm{pH}$, however, also affects mineral solubility, and at lower $\mathrm{pH}$ the toxicity of metals and organic acids are often 


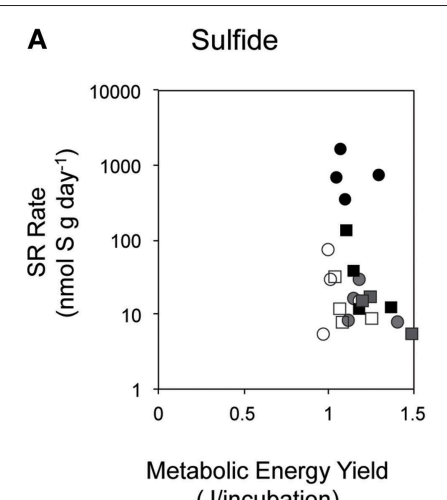

(J/incubation)
B

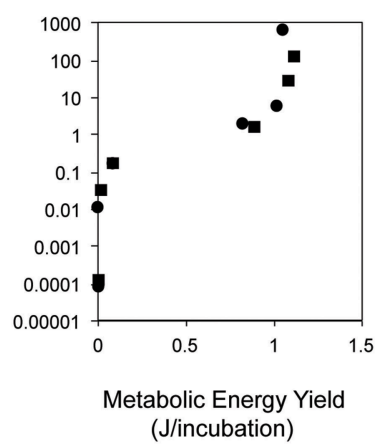

C DOC

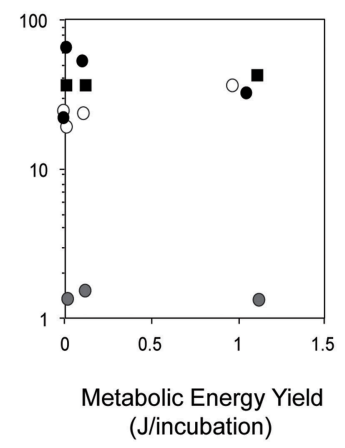

○ pH $6 @ 4^{\circ} \mathrm{C} \bullet \mathrm{ph} 6 @ 50^{\circ} \mathrm{C}$ opH $6 @ 90^{\circ} \mathrm{C}$

$\square \mathrm{pH} 4 @ 4^{\circ} \mathrm{C}=\mathrm{pH} 4 @ 50^{\circ} \mathrm{C} \mathrm{pH} 4 @ 90^{\circ} \mathrm{C}$

FIGURE 7 | Relationship between metabolic energy available from sulfate reduction and empirically measured rates of SR in incubations with varying concentrations of (A) sulfide, (B) sulfate, and (C) DOC are shown here at $4^{\circ} \mathrm{C}$ (white), $50^{\circ} \mathrm{C} \mathrm{(black),} \mathrm{and} 90^{\circ} \mathrm{C} \mathrm{(gray),} \mathrm{and} \mathrm{at} \mathrm{pH} 6$ (circle) or pH 4 (square).

elevated as minerals are solubilized and organic acids become protonated (Ghose and Wiken, 1955; Oleszkiewicz et al., 1989; Giller et al., 1998; Gadd and Griffiths, 2013). For example, at low $\mathrm{pH}$, the carboxyl groups of simple organic acids are primarily undissociated, allowing them to pass across the cell membrane where they can uncouple electrochemical gradients (Ghose and Wiken, 1955). Of particular concern in hydrothermal environments is the dissolution of metal sulfides, which is enhanced at lower $\mathrm{pH}$ and depends on sulfide concentrations. To evaluate the potential for metal toxicity in our incubations, we calculated in situ activities of Fe, $\mathrm{Zn}$, and $\mathrm{Cu}$ (assuming in situ end-member concentrations; Butterfield et al., 1994), which are known to be toxic when dissolved and in sufficient concentration. The activities of $\mathrm{Fe}, \mathrm{Zn}$, and $\mathrm{Cu}$ were elevated at lower $\mathrm{pH}$, and several metal sulfides and iron oxides were supersaturated under the high aqueous sulfide incubation conditions. We investigated the possibility that high sulfide amendments drew down trace metal concentration via mineral precipitation, thus explaining the increases in SR rates with increasing sulfide concentration. To account for mineral precipitation resulting from sulfide addition, we performed a single-point reaction path calculation to constrain the expected aqueous metal activities as functions of both $\mathrm{pH}$ and sulfide concentration. The fluid speciation models assumed initial trace metal concentrations from endmember fluid analyses (Butterfield et al., 1994) and allowed minerals to reach supersaturation resulting in aqueous activities of $\sim 10^{-5.3}$ and $\sim 10^{-3.7}, \mathrm{Cu}^{2+}$ and $\mathrm{Fe}^{2+}$ respectively. High sulfide concentrations likely led to abiotic mineral precipitation in the incubation experiments, leading to the drawdown of trace metal concentrations. Accounting for amended sulfide concentrations, in situ $\mathrm{pH}$, and mineral precipitation (primarily pyrite, hematite and covellite), activities of $\mathrm{Cu}^{2+}$ and $\mathrm{Fe}^{2+}$ were reduced to $10^{-13}$ and $\sim 10^{-4.5}$, respectively, depending on $\mathrm{pH}$ (Figure 8). Precipitation of these metal sulfides also lowered the calculated fluid $\mathrm{pH}$, an effect that was more pronounced for $\mathrm{pH}$ 6 incubations (final fluid $\mathrm{pH} \sim 4$ after mineral precipitation) than in $\mathrm{pH} 4$ incubations (final $\mathrm{pH} \sim 3.3$ ). While we could not monitor $\mathrm{pH}$ during the radiolabeled experiments, these values are within the range expected for Grotto chimney environments, and the effect was minimal for $\mathrm{pH} 4$ incubations.

Because the sulfate reducing organisms in this study are embedded within a metal sulfide matrix, the most feasible explanation for the pattern of increasing SR rates observed at $\mathrm{pH} 4$ with increasing sulfide (Figure 4B) is attenuation of metal toxicity by metal-sulfide precipitation (Figure 8). In pure cultures of Thermococcus fumicolans, Pyrococcus strain GB-D, Methanocaldococcus jannaschii, sulfide additions were shown to attenuate the toxic effects of metal cations by forming metalsulfide complexes (Edgcomb et al., 2004). In our incubation experiments, the reduction of aqueous $\mathrm{Cu}^{2+}$ (and to a lesser extent $\mathrm{Fe}^{2+}$ ) via mineral precipitation, particularly at high sulfide concentrations, likely attenuated metal toxicity to native sulfate reducers. The free metal activities were below the ranges that have been found to be toxic to sulfate reducing bacteria (e.g., $10^{-3.1}$ to $10^{-4.33}$ for $\mathrm{Cu}^{2+}$ (Booth and Mercer, 1963; Saleh et al., 1964; Temple and Le Roux, 1964; Hao et al., 1994; Sani et al., 2001; Utgikar et al., 2002, 2003; Figure 8A). These patterns are particularly pronounced for $\mathrm{Cu}^{2+}$ and correlation between SR rates and aqueous $\mathrm{Cu}^{2+}$ activities suggests that metal-sulfide precipitation and the resulting decrease in metal toxicity can account for increasing SR rates at high sulfide concentrations (Figure 8B). The effect is even more apparent at $\mathrm{pH} 4$ (e.g., a 10 -fold decrease in SR rates as $\mathrm{Cu}^{2+}$ activities increase) likely because cells are already compromised by the low $\mathrm{pH}$.

\section{Energetic Constraints of SR Rates}

Substrate availability and uptake mechanisms subtly influence the magnitude of SR rates in Grotto flanges. The MichaelisMenten constants (or $K_{m}$, defined as the sulfate concentration at which the reaction rate is at half-maximum) calculated for Grotto are higher than the range of $K_{m}$ values calculated for SR in marine sediments $(0.204-1.63 \mathrm{mM}$; Boudreau and 

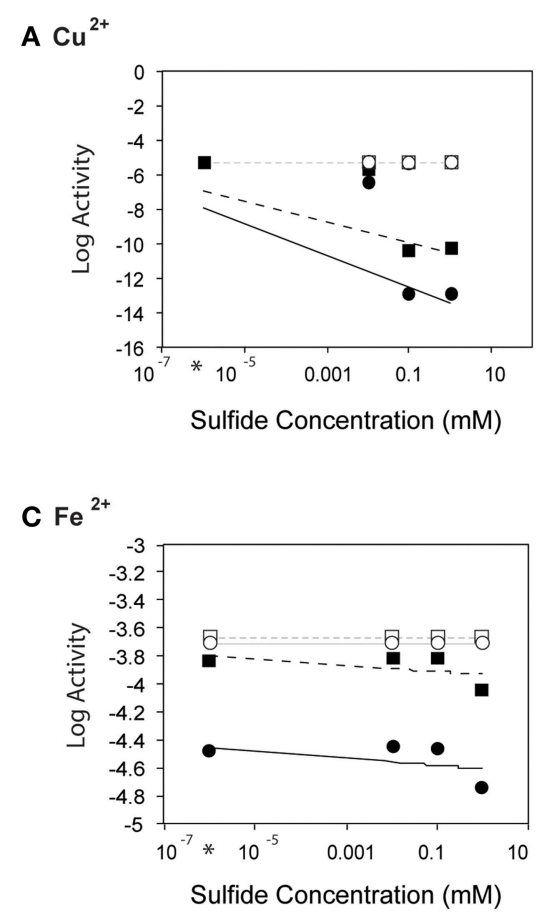

B $\mathrm{Cu}^{2+}$

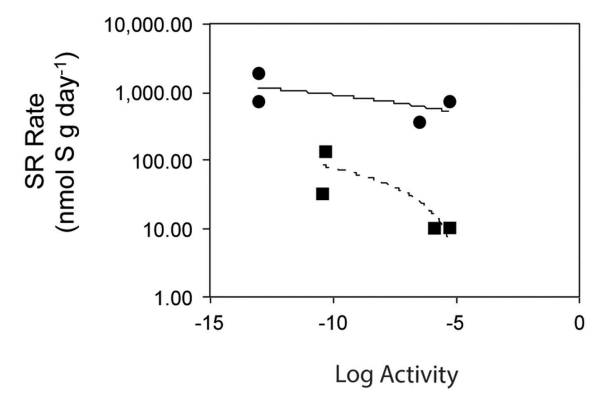

D $\mathrm{Fe}^{2+}$

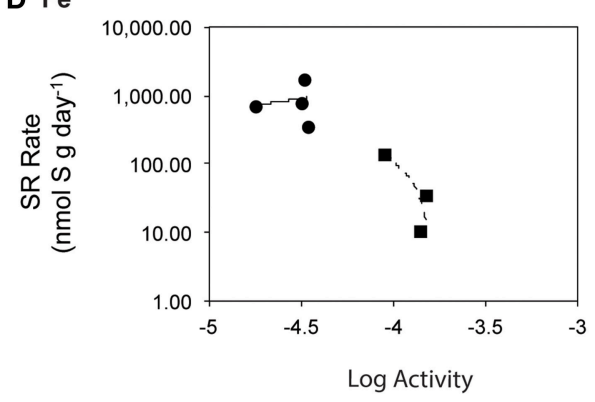

- ph $6 @ 50^{\circ} \mathrm{C} \quad$ - pH $4 @ 50^{\circ} \mathrm{C}$

— ph 6 Trendline ---- pH 4 Trendline

FIGURE 8 | Initial sulfide concentration and the log activities of (A) $\mathrm{Cu}^{2+}$ and (C) $\mathrm{Fe}^{2+}$ at $50^{\circ} \mathrm{C}$ (as calculated by EQ3/6) and pH of $4(\mathrm{O})$ or $6(\square)$ are

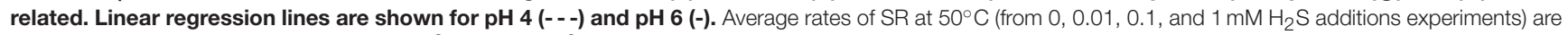
plotted with respect to log activities of (B) $\mathrm{Cu}^{2+}$ and (D) $\mathrm{Fe}^{2+}$. Note that activity is a measure of the effective concentration of a species within a fluid.

Westrich, 1984; Kostka et al., 2002; Roychoudhury et al., 2003; Pallud and Van Cappellen, 2006), low sulfate environments (10-70 $\mathrm{M}$; Ingvorsen et al., 1981; Lovley et al., 1982), and marine sulfate reducers in pure culture (3.0-330 $\mu \mathrm{M}$; Ingvorsen et al., 1981; Ingvorsen and Jørgensen, 1984; Sonne-hansen and Westermann, 1999). One plausible explanation for why $K_{m}$ values for hydrothermal SR are higher than in other marine systems, is that the cellular uptake of sulfate is less efficient in hydrothermal sulfate reducers. Since all the enzymes required to catalyze sulfate into hydrogen sulfide are located in the interior of a cell (cytoplasm or associated with the inner surface of the cytoplasmic membrane), sulfate must be transported into the cells in order to be utilized. Due to the high sulfate concentration in seawater, marine SR communities often utilize low affinity transport mechanisms such as cation dependent passive transport (Cypionka and Konstanz, 1989; Kreke and Cypionka, 1992, 1994, 1995) but can switch to active transport via sulfate permeases (Piłsyk and Paszewski, 2009) under sulfate limitation (Tarpgaard et al., 2011). In comparison to marine systems, hydrothermal sulfide deposit environments have higher metal and $\mathrm{H}_{2} \mathrm{~S}$ loads, lower relative sulfate and experience higher temperature and lower $\mathrm{pH}$ fluids. Higher $K_{m}$ values at vents may be a result of insoluble metal sulfides acting as barriers to prevent the transport of sulfate (or other substrate) into the cell (Utgikar et al., 2002). Hydrothermal communities may mediate the potentially inhibitory effects of high temperature, low $\mathrm{pH}$ and sulfate limitation by increasing the number or type of sulfate permeases per cell. Our data suggests that sulfate reducers have a higher affinity for sulfate at $\mathrm{pH} 4$ than at $\mathrm{pH} 6$ and may utilize different mechanisms (like increasing the number or type of sulfate permeases utilized) to overcome $\mathrm{pH}$-induced constraints to maintain constant rates of SR.

It is also important to note that Michaelis-Menten kinetic models, and calculated values of $K_{m}$, are based on idealized growth conditions, including optimized physiological parameters, single limiting substrates (e.g., sulfate), the absence of inhibitory mechanisms, and no community members of competition in the community structure. For example, our values of $K_{m}$ assume that sulfate is the sole limiting substrate, however calculated energy densities (Figure 5Bv) indicate this is not always, or even usually, the case in this system. Interestingly, the measured rates, at $14 \mathrm{mM}$ sulfate, are comparable in magnitude to hydrothermally influenced sediments from Guaymas basin (high sulfate; Jørgensen et al., 1990; Elsgaard et al., 1994a) and Lake Tanganyika (low sulfate; Elsgaard et al., 1994b), which have strikingly different sulfate concentrations, suggesting that sulfate concentration alone may not govern the overall kinetics of SR. Considering this, it is more likely that energy availability in the context of substrate availability 
is constraining the magnitude of rates and complicating the Michaelis-Menten kinetics pattern we might expect.

Substrate limitation is often concomitant with energy-limited conditions. Minimal energy requirements for autotrophic SR in marine sediments are inferred to be $-19.1 \mathrm{~kJ} / \mathrm{mol} \mathrm{SO} \mathrm{SO}_{4}^{2-}$ (Hoehler et al., 2001) and it has been suggested that these minimal requirements are always easily met for heterotrophic metabolisms (Lever et al., 2015). Regardless, our values of Gibbs free energy yields, normalized per mole of sulfate (ca. -100 to $-150 \mathrm{~kJ} / \mathrm{mol} \mathrm{SO}_{4}^{2-}$ ), greatly exceed the minimum energy requirements for autotrophic sulfate reduction. Thus, it is unlikely that metabolic energy availability was limiting in most conditions in our experiments. Nonetheless, SR rates are positively correlated with metabolic energy availability (Figure 7B; Kendal rank correlation $p<0.005$ ), suggesting that energy availability still plays a role in microbial metabolic rates, even if it is not limiting microbial growth. Furthermore, the energy available for SR across most conditions within these incubations could support $\sim 10^{5}-10^{6}$ cells $\bullet$ matrix $^{-1}$ [assuming that $10 \%$ of that energy supports growth, cellular synthesis requires $1434 \mathrm{~J} \bullet \mathrm{g}$ cell in anoxic environments (McCollom and Amend, 2005), the abundance of SR bacteria and archaea in situ is $10^{3}-10^{4}$ cells $\bullet$ matrix $^{-1}$ (Frank et al., 2013), and cells have 1 $d s r A$ gene copy (Klein et al., 2001; Kondo et al., 2004)]. Even at the lowest values of sulfate, $10 \mathrm{nM}$, the energy within the system could support $\sim 100$ cells/g mineral.

Interestingly, high rates of SR were observed even when metabolic energy yield was assumed to be low, based on the exogenous DOC concentration provided in each batch reaction (Figure 7C). This suggests that we underestimated the energy yield provided in each batch reaction and did not take into consideration potential sources of endogenous carbon within the mineral inoculum. Heterotrophic SR utilizing a wide variety of metabolic products has been shown to be thermodynamically favorable in hydrothermal environments based on concentrations in diffuse fluid (Rogers and Amend, 2006). Mineral associated products of microbial respiration or fermentation and lysed cells are likely other sources of endogenous organic carbon. Perhaps more important is the contribution of remnants from associated macrofauna as the surface of the Grotto flange was heavily colonized by tubeworms. Tube worm growth provides structural scaffolding for the concentration and precipitation of minerals during the initial stages of hydrothermal chimney and flange formation (Kristall et al., 2006) and fossilized tube structures have been observed within mineralogical samples of Grotto deposits (Tivey et al., 1999). Reasonably, dead macrofauna-heterogeneously distributed within the walls of a hydrothermal deposit-may provide localized and concentrated sources of carbon for microbial utilization and sulfate reduction.

Currently, our assumptions of the amount of carbon available within the mineral matrix of hydrothermal vents is based solely on DOC measurements from end-member and diffuse flow (Lang et al., 2006, 2010). However, these fluid measurements may only place lower bounds on carbon availability in hydrothermal systems. Unfortunately, concentrations of mineral associated carbon (or total organic carbon) have not been evaluated, due to technical complications, in hydrothermal chimneys. The only measurements of the total organic carbon (TOC) in similar mineral hosted systems across the Juan de Fuca Ridge are in sediments and values (wt\%) vary between 0.06 and $0.83 \%$ and hydrolysable amino acids account for up to $3.3 \%$ of this organic carbon (Andersson et al., 2000). If we assume a maximum density of $10^{8}$ cellsøg matrix ${ }^{-1}$ (Schrenk et al., 2003), and the average carbon content of $12.4 \pm 6.3 \mathrm{fg} \mathrm{C}$ per oceanic bacterial cell (Fukuda et al., 1998) that's roughly $12.4 \mu \mathrm{g} \mathrm{C} \bullet \mathrm{g}$ matrix $^{-1}(0.0012 \%$ by weight $)$ that could be respired, and could support $0.0341 \mathrm{~J} \bullet$ matrix $^{-1}$ of energy for sulfate reduction. Energy from the recycling of bacterial biomass alone would be enough to support $10^{5}$ cells $\bullet$ matrix $^{-1}$, and these calculations do not even include potential carbon estimations from eukaryotic input. Similarly, recent studies suggest that the degradation of subsurface microbial biomass may be an important source of organic matter in unsedimented hydrothermal systems and expands the types of heterotrophic metabolic strategies thought possible in these environments (Reeves et al., 2014). These data suggest that hydrothermal chimneys may contain a substantially greater amount of biologically available endogenous carbon to support heterotrophic metabolisms than has previously been considered by bioenergetic models. DOC and TOC measurements at vents are relatively sparse and a more thorough documentation of these values across vent fields would be incredibly valuable to re-evaluate the potential energy yields of heterotrophic metabolisms in hydrothermal systems.

We cannot overlook the possibility of substrate competition among in situ microorganisms utilizing alternate metabolisms. However, because these experiments were incubated in the absence of nitrate and hydrogen, potential competition with denitrifiers or any autotrophic metabolisms can be excluded in our reactions. Furthermore, data from numerous studies suggest that under these experimental conditions heterotrophic sulfate reducers would outcompete methanogenic bacteria (Oremland and Taylor, 1977; Oremland and Polcin, 1982; Lovley and Klug, 1986; Weijma et al., 2000). While many organisms capable of iron reduction have been isolated from vents (Takai et al., 2000; Kashefi et al., 2002; Hirayama et al., 2007; Sokolova et al., 2007; Slobodkina et al., 2009), the mineralogy of Grotto-reduced iron minerals (Tivey and Delaney, 1986; Delaney et al., 1992)- suggests limited influence from iron reducers under these experimental conditions.

\section{CONCLUDING REMARKS}

Multivariate experiments that couple empirically derived data and bioenergetic modeling can significantly advance our understanding of SR within complex hydrothermal systems by placing constraints on the factor(s) most likely governing SR activity at in situ conditions. Moving toward a better understanding of SR-and associated processes-in the natural world requires that processes are studied at conditions relevant to those found in situ. Indeed, the factors governing SR in situ are complex, sufficiently so as to make it difficult to establish causality with a high degree of certainty. That said, this work underscores the relevance of interactions among 
physico-chemical conditions, water-rock reactions, microbial physiology, and metabolic energetics, and their combined effect on microbial activity. These findings suggest that the variability in sulfate reduction rates reflect the response of the active microbial consortia to environmental constraints on in situ microbial physiology, toxicity, and the type and extent of energy limitation. These results further emphasize that the effect of in situ metabolic reaction energetics is minimal under energy-rich conditions (Jin and Bethke, 2007), but likely play an important role under energy-limiting conditions and during competition. The data presented here highlight the significance of sulfate reduction in hydrothermal chimneys and provide a framework for continued studies of sulfur cycling along mid-ocean ridge systems.

It is important to recognize that geochemical models of metabolic energy availability, even when considering in situ fluid chemistry, cannot explain microbial activity, like SR rates, in all systems. Ideally future studies would couple fine-scale in situ redox measurements and microbial sampling with bioenergetic modeling and direct measurements of metabolic rates in order to more explicitly constrain microbial niches across steep redox gradients. Integrating analyses of the microbial community composition and structure, metagenomic reconstructions of energy metabolisms, and measured rates of metabolic activities of hydrothermal chimney microbes can provide specific evidence to test energetic hypothesizes. Only by concurrently assessing these biological and geochemical data can we begin to understand

\section{REFERENCES}

Alazard, D., Dukan, S., Urios, A., Verhe, F., Bouabida, N., Morel, F., et al. (2003). Desulfovibrio hydrothermalis $\mathrm{sp}$ nov., a novel sulfate-reducing bacterium isolated from hydrothermal vents. Int. J. Syst. Evol. Microbiol. 53, 173-178. doi: 10.1099/ijs.0.02323-0

Amend, J. P., McCollom, T. M., Hentscher, M., and Bach, W. (2011). Catabolic and anabolic energy for chemolithoautotrophs in deep-sea hydrothermal systems hosted in different rock types. Geochim. Cosmochim. Acta, 75, 5736-5748. doi: 10.1016/j.gca.2011.07.041

Amend, J. P., and Rogers, K. L., Meyer-Dombard, D. R. (2004). "Microbially mediated sulfur-redox: energetics in marine hydrothermal vent systems," in Sulfur Biogeochemistry: Past and Present, eds J. P. Amend, K. J. Edwards, and T. W. Lyons (Boulder, CO: Geological Society of America), 17-34.

Amend, J. P., Rogers, K. L., Shock, E. L., Gurrieri, S., and Inguaggiato, S. (2003). Energetics of chemolithoautotrophy in the hydrothermal system of Vulcano Island, southern Italy. Geobiology 1, 37-58. doi: 10.1046/j.14724669.2003.00006.x

Amend, J. P., and Shock, E. L. (2001). Energetics of overall metabolic reactions of thermophilic and hyperthermophilic Archaea and Bacteria. FEMS Microbiol. Rev. 25, 175-243. doi: 10.1111/j.1574-6976.2001.tb00576.x

Andersson, E., Simoneit, B. R. T., and Holm, N. G. (2000). Amino acid abundances and stereochemistry in hydrothermally altered sediments from the Juan de Fuca Ridge, northeastern Pacific Ocean. Appl. Geochem. 15, 1169-1190. doi: 10.1016/S0883-2927(99)00110-9

Audiffrin, C., Cayol, J. L., Joulian, C., Casalot, L., Thomas, P., Garcia, J. L., et al. (2003). Desulfonauticus submarinus gen. nov., sp nov., a novel sulfate-reducing bacterium isolated from a deep-sea hydrothermal vent. Int. J. Syst. Evol. Microbiol. 53, 1585-1590. doi: 10.1099/ijs.0. 02551-0

Booth, G. H., and Mercer, S. J. (1963). Resistance to copper of some oxidizing and reducing bacteria. Nature 199:622. doi: 10.1038/199622a0

Bostick, B. C., Fendorf, S., and Helz, G. R. (2003). Differential adsorption of molybdate and tetrathiomolybdate on pyrite $\left(\mathrm{FeS}_{2}\right)$. Environ. Sci. Technol. 37, 285-291. doi: 10.1021/es0257467 the relationship between vent geochemistry and the prolific and diverse communities observed therein, as well as their impact on global biogeochemical cycles of sulfur and carbon.

\section{ACKNOWLEDGMENTS}

Financial support for this research was provided by the Nation Science Foundation (OCE-0838107 and OCE-1061934 to PG), the National Aeronautic and Space Administration (NASAASTEP NNX09AB78G to C. Scholin and PG and NASA-ASTEP NNX07AV51G to A. Knoll and PG) and the Center for Dark Energy Biosphere Investigations (C-DEBI graduate fellowship support to KF). We are grateful for the expert assistance of the $R / V$ Atlantis crews and the pilots and team of the DSV Jason for enabling the collections of hydrothermal deposits used in our experiments. We also thank Steve Sansone, Joseph Ring, Julie Hanlon, Colleen Cavanaugh, Heather Olins, John Skutnik, Mark Nielson and Victoria Bertics for providing assistance with various technical aspects of the experiments.

\section{SUPPLEMENTARY MATERIAL}

The Supplementary Material for this article can be found online at: http://journal.frontiersin.org/article/10.3389/fmicb. 2015.01449

Boudreau, B., and Westrich, J. (1984). The dependence of bacterial sulfate reduction on sulfate concentration in marine sediments. Geochim. Cosmochim. 48, 2503-2516. doi: 10.1016/0016-7037(84)90301-6

Butterfield, D. A., McDuff, R. E., Mottl, M. J., Lilley, M. D., Lupton, J. E., and Massoth, G. J. (1994). Gradients in the composition of hydrothermal fluids from the Endeavour segment vent field: phase separation and brine loss. J. Geophys. Res. 99, 9561-9583. doi: 10.1029/93JB03132

Canfield, D. E. (1989). Sulfate Reduction and oxic respiration in marinesediments- Implications for organic-carbon preservation in euxinic envrionments. Deep Sea Res. A Oceanogr. Res. Pap. 36, 121-138. doi: 10.1016/0198-0149(89)90022-8

Canfield, D. E., Stewart, F. J., Thamdrup, B., De Brabandere, L., Dalsgaard, T., Delong, E. F., et al. (2010). A cryptic sulfur cycle in oxygenminimum-zone waters off the Chilean coast. Science 330, 1375-1378. doi: 10.1126/science.1196889

Church, C. D., Wilkin, R. T., Alpers, C. N., Rye, R. O., and McCleskey, R. B. (2007). Microbial sulfate reduction and metal attenuation in $\mathrm{pH} 4$ acid mine water. Geochem. Trans. 8:10. doi: 10.1186/1467-4866-8-10

Cypionka, H., and Konstanz, U. (1989). Characterization of sulfate transport in Desulfovibrio desulfuricans. Arch. Microbiol. 152, 237-243. doi: 10.1007/BF00409657

D’Hondt, S., Jørgensen, B. B., Miller, D. J., Batzke, A., Blake, R., Cragg, B. A., et al. Guerin, G. (2004). Distributions of microbial activities in deep subseafloor sediments. Science 306, 2216-2221. doi: 10.1126/science.1101155

Delaney, J. R., Robigou, V., McDuff, R. E., and Tivey, M. K. (1992). Geology of a vigorous hydrothermal system on the Endeavor segment, Juan de Fuca ridge. J. Geophys. Res. Earth 97, 19663-19682. doi: 10.1029/92JB00174

Detmers, J., Brüchert, V., and Habicht, K. S. (2001). Diversity of sulfur isotope fractionations by sulfate-reducing prokaryotes. Appl. Environ. Microbiol. 67, 888-894. doi: 10.1128/AEM.67.2.888-894.2001

Dittmar, W. (1884). Report on researches into the composition of ocean water, collected by the HMS Challenger, during the years 1873-1876. Rept. Sci. Results Voyag. H.M.S. Chall. (Phys. Chem.), 1, 1-251.

Edgcomb, V. P., Molyneaux, S. J., Saito, M. A., Lloyd, K., Böer, S., Wirsen, C. O., et al. (2004). Sulfide ameliorates metal toxicity for deep-sea hydrothermal vent 
archaea. Appl. Environ. Microbiol. 70, 2551-2555. doi: 10.1128/AEM.70.4.25512555.2004

Elsgaard, L., Isaksen, M. F., Jørgensen, B. B., Alayse, A. M., and Jannasch, H. W. (1994a). Microbial sulfate reduction in deep-sea sediments at the Guaymas Basin hydrothermal vent area: influence of temperature and substrates. Geochim. Cosmochim. Acta, 58, 3335-3343. doi: 10.1016/0016-7037(94) 90089-2

Elsgaard, L., Prieur, D., Mukwaya, G. M., and Jørgensen, B. B. (1994b). Thermophilic sulfate reduction in hydrothermal sediment of lake tanganyika, East Africa. Appl. Environ. Microbiol. 60, 1473-1480.

Engelen, B., Ziegelmüller, K., Wolf, L., Köpke, B., Gittel, A., Cypionka, H., et al. (2008). Fluids from the oceanic crust support microbial activities within the deep biosphere. Geomicrobiol. J. 25, 56-66. doi: 10.1080/01490450701829006

Fike, D. A., Gammon, C. L., Ziebis, W., and Orphan, V. J. (2008). Micronscale mapping of sulfur cycling across the oxycline of a cyanobacterial mat: a paired nanoSIMS and CARD-FISH approach. ISME J. 2, 749-759. doi: 10.1038/ismej.2008.39

Fossing, H., and Jørgensen, B. B. (1989). Measurment of bacterial sulfate reduction in sediments- evaluation of a single-step chromium reduction method. Biogeochemistry 8, 205-222. doi: 10.1007/BF00002889

Frank, K. L., Rogers, D. R., Olins, H. C., Vidoudez, C., and Girguis, P. R. (2013). Characterizing the distribution and rates of microbial sulfate reduction at Middle Valley hydrothermal vents. ISME 7, 1391-1401. doi: 10.1038/ismej.2013.17

Fukuda, R., Ogawa, H., and Nagata, T. (1998). Direct determination of carbon and nitrogen contents of natural bacterial assemblages in marine environments. Appl. Environ. Microbiol. 64, 3352-3358.

Gadd, G. M., and Griffiths, A. J. (2013). Microorganisms and heavy metal toxicity. Microb. Ecol. 4, 303-317. doi: 10.1007/BF02013274

Ghose, T., and Wiken, T. (1955). Inhibition of bacterial sulphate-reduction in presence of short chain fatty acids. Physiol. Plant. 8, 116-134. doi: 10.1111/j.1399-3054.1955.tb08965.x

Giller, K. E., Witter, E., and McGrath, S. P. (1998). Toxicity of heavy metals to microorganisms and microbial processes in agricultural soils: a review. Soil Biol. Biochem. 30, 1389-1414. doi: 10.1016/S0038-0717(97)00270-8

Hao, O. J., Huang, L., Chen, J. M., and Buglass, R. L. (1994). Effects of metal additions on sulfate reduction activity in wastewaters. Toxicol. Environ. Chem. 46, 197-212. doi: 10.1080/02772249409358113

Harmsen, H. J. M., Prieur, D., and Jeanthon, C. (1997). Distribution of microorganisms in deep-sea hydrothermal vent chimneys investigated by whole-cell hybridization and enrichment culture of thermophilic subpopulations. Appl. Environ. Microbiol. 63, 2876-2883.

Hirayama, H., Sunamura, M., Takai, K., Nunoura, T., Noguchi, T., Oida, H., et al. Horikoshi, K. (2007). Culture-dependent and -independent characterization of microbial communities associated with a shallow submarine hydrothermal system occurring within a coral reef off Taketomi Island, Japan. Appl. Environ. Microbiol. 73, 7642-7656. doi: 10.1128/AEM.01258-07

Hoehler, T. M., Alperin, M. J., Albert, D. B., and Martens, C. S. (2001). Apparent minimum free energy requirements for methanogenic Archaea and sulfatereducing bacteria in an anoxic marine sediment. FEMS Microbiol. Ecol. 38, 33-41. doi: 10.1111/j.1574-6941.2001.tb00879.x

Hoek, J., Banta, A., Hubler, F., and Reysenbach, A. L. (2003). Microbial diversity of a sulphide spire located in the Edmond deep-sea hydrothermal vent field on the Central Indian Ridge. Geobiology 1, 119-127. doi: 10.1046/j.14724669.2003.00015.x

Holmkvist, L., Ferdelman, T. G., and Jørgensen, B. B. (2011a). A cryptic sulfur cycle driven by iron in the methane zone of marine sediment (Aarhus Bay, Denmark). Geochim. Cosmochim. Acta 75, 3581-3599. doi: 10.1016/j.gca.2011.03.033

Holmkvist, L., Kamyshny, A. Jr., Vogt, C., Vamvakopoulos, K., Ferdelman, T. G., and Jørgensen, B. B. (2011b). Sulfate reduction below the sulfate-methane transition in Black Sea sediments. Deep Sea Res. I Oceanogr. Res. Pap. 58, 493-504. doi: 10.1016/j.dsr.2011.02.009

Huber, H., Jannasch, H., Rachel, R., Fuchs, T., and Stetter, K. O. (1997). Archaeoglobus veneficus sp nov, a novel facultative chemolithoautotrophic hyperthermophilic sulfite reducer, isolated from abyssal black smokers. Syst. Appl. Microbiol. 20, 374-380. doi: 10.1016/S0723-2020(97)80005-7

Ingvorsen, K., and Jørgensen, B. B. (1984). Kinetics of sulfate uptake by freshwater and marine species of Desulfovibrio. Arch. Microbiol. 139, 61-66. doi: $10.1007 /$ BF00692713
Ingvorsen, K., Zeikus, J. G., and Brock, T. D. (1981). Dynamics of bacterial sulfate reduction in a eutrophic lake. Appl. Environ. Microbiol. 42, 1029-1036.

Isaksen, M. F., Bak, F., and Jørgensen, B. B. (1994). Thermophilic sulfatereducing bacteria in cold marine sediment. FEMS Microbiol. Ecol. 14, 1-8. doi: 10.1111/j.1574-6941.1994.tb00084.x

Jannasch, H. W., Wirsen, C. O., Molyneaux, S. J., and Langworthy, T. A. (1988). Extremely thermophilic fermentative archaebacteria of the genus Desulfurococcus from deep-sea hydrothermal vents. Appl. Environ. Microbiol. 54, 1203-1209.

Jeanthon, C., Haridon, L., Cueff, V., Banta, A., Reysenbach, A., and Prieur, D. (2002). Thermodesulfobacterium hydrogeniphilum sp. nov., a thermophilic, chemolithoautotrophic, sulfate-reducing bacterium isolated from a deep-sea hydrothermal vent at Guaymas Basin. Int. J. Syst. Evol. Microbiol. 52, 765-772. doi: 10.1099/00207713-52-3-765

Jin, Q., and Bethke, C. M. (2007). The thermodynamics and kinetics of microbial metabolism. Am. J. Sci. 307, 643-677. doi: 10.2475/04.2007.01

Jin, Q. S., and Bethke, C. M. (2005). Predicting the rate of microbial respiration in geochemical environments. Geochim. Cosmochim. Acta 69, 1133-1143. doi: 10.1016/j.gca.2004.08.010

Johnson, J. W., Oelkers, E. H., and Helgeson, H. C. (1992). SUPCRT92: a software package for calculating the standard molal thermodynamic properties of minerals, gases, aqueous species, and reactions from 1 to 5000 bar and 0 to $1000^{\circ}$ C. Comput. Geosci. 18, 899-947. doi: 10.1016/0098-3004(92)90029-Q

Jørgensen, B. B., and Bak, F. (1991). Pathways and microbiology of thiosulfate transformations and sulfate reduction in a marine sediment (Kattegat, Denmark). Appl. Environ. Microbiol. 57, 847-856.

Jørgensen, B. B., and Fenchel, T. (1974). The sulfur cycle of a marine sediment model system. Mar. Biol. 24, 189-201. doi: 10.1007/BF00391893

Jørgensen, B. B., Isaksen, M. F., and Jannasch, H. W. (1992). Bacterial sulfate reduction above 100-degrees-C in deep-sea hydrothermal vent sediments. Science (80-.). 258, 1756-1757. doi: 10.1126/science.258.5089.1756

Jørgensen, B. B., Zawacki, L. X., and Jannasch, H. W. (1990). Thermophilic bacterial sulfate reduction in deep-sea sediments at the Guaymas Basin hydrothermal vent site (Gulf of California). Deep Sea Res. A Oceanogr. Res. Pap. 37, 695-710. doi: 10.1016/0198-0149(90)90099-H

Joye, S. B., Boetius, A., Orcutt, B. N., Montoya, J. P., Schulz, H. N., Erickson, M. J., et al. (2004). The anaerobic oxidation of methane and sulfate reduction in sediments from Gulf of Mexico cold seeps. Chem. Geol. 205, 219-238. doi: 10.1016/j.chemgeo.2003.12.019

Kallmeyer, J., and Boetius, A. (2004). Effects of temperature and pressure on sulfate reduction and anaerobic oxidation of methane in hydrothermal sediments of Guaymas Basin. Appl. Environ. Microbiol. 70, 1231-1233. doi: 10.1128/AEM.70.2.1231-1233.2004

Kallmeyer, J., Ferdelman, T. G., and Jørgensen, B. B. (2002). Sulfate reduction rates in deeply, buried marine sediments. Geochim. Cosmochim. 66, A378.

Kallmeyer, J., Ferdelman, T. G., Weber, A., Fossing, H., and Jorgensen, B. B. (2004a). A cold chromium distillation procedure for radiolabeled sulfide applied to sulfate reduction measurements. Limnol. Oceanogr. 2, 171-180. doi: 10.4319/lom.2004.2.171

Kallmeyer, J., Ferdelman, T. G., Weber, A., Fossing, H., and Jørgensen, B. B. (2004b). Evaluation of a cold chromium distillation procedure for recovering very small amounts of radiolabeled sulfide related to sulfate reduction measurements. Limnol. Oceanogr. Methods, 2, 171-180. doi: 10.4319/lom.2004.2.171

Kashefi, K., Tor, J. M., Holmes, D. E., Gaw Van Praagh, C. V., Reysenbach, A.-L., and Lovley, D. R. (2002). Geoglobus ahangari gen. nov., sp. nov., a novel hyperthermophilic archaeon capable of oxidizing organic acids and growing autotrophically on hydrogen with $\mathrm{Fe}(\mathrm{III})$ serving as the sole electron acceptor. Int. J. Syst. Evol. Microbiol. 52, 719-728. doi: 10.1099/0020771352-3-719

Klein, M., Friedrich, M., Roger, A. J., Hugenholtz, P., Fishbain, S., Abicht, H., et al. Linda, L. (2001). Multiple lateral transfers of dissimilatory sulfite reductase genes between major lineages of sulfate-reducing prokaryotes. Appl. Environ. Microbiol. 183 6028-6035. doi: 10.1128/jb.183.20.6028-6035.2001

Kondo, R., Nedwell, D. B., Purdy, K. J., and Silva, S. Q. (2004). Detection and enumeration of sulphate-reducing bacteria in estuarine sediments by competitive PCR. Geomicrobiol. J. 21, 145-157. doi: $10.1080 / 01490450490275307$

Kormas, K. A., Tivey, M. K., Von Damm, K., and Teske, A. (2006). Bacterial and archaeal phylotypes associated with distinct mineralogical layers of a white 
smoker spire from a deep-sea hydrothermal vent site ( 9 degrees N, East Pacific Rise). Environ. Microbiol. 8, 909-920. doi: 10.1111/j.1462-2920.2005.00978.x

Koschorreck, M. (2008). Microbial sulphate reduction at a low pH. FEMS Microbiol. Ecol. 64, 329-342. doi: 10.1111/j.1574-6941.2008.00482.x

Kostka, J. E., Roychoudhury, A., and Van Cappellen, P. (2002). Rates and controls of anaerobic microbial respiration across spatial and temporal gradients in saltmarsh sediments. Biogeochemistry 60, 49-76. doi: 10.1023/A:1016525216426

Kreke, B., and Cypionka, H. (1992). Protonmotive force in freshwater sulfatereducing bacteria, and its role in sulfate accumulation in Desulfobulbus propionicus. Arch. Microbiol. 158, 183-187. doi: 10.1007/BF00290814

Kreke, B., and Cypionka, H. (1994). Role of sodium ions for sulfaate transport and energy metabolism in Desulfovibrio salexigens. Arch. Microbiol. 161, 55-61. doi: $10.1007 / \mathrm{BF} 00248893$

Kreke, B., and Cypionka, H. (1995). Energetics of sulfate transport in Desulfomicrobium baculatum. Arch. Microbiol. 163, 307-309. doi: 10.1007/ BF00393385

Kristall, B., Kelley, D. S., Hannington, M. D., and Delaney, J. R. (2006). Growth history of a diffusely venting sulfide structure from the Juan de Fuca Ridge: a petrological and geochemical study. Geochem. Geophys. Geosyst. 7, 1-30. doi: $10.1029 / 2005 \mathrm{gc} 001166$

Lang, S. Q., Butterfield, D. A., Lilley, M. D., Johnson, H. P., and Hedges, J. I. (2006). Dissolved organic carbon in ridge-axis and ridge-flank hydrothermal systems. Geochim. Cosmochim. Acta 70, 3830-3842. doi: 10.1016/j.gca.2006.04.031

Lang, S. Q., Butterfield, D. A., Schulte, M., Kelley, D. S., and Lilley, M. D. (2010). Elevated concentrations of formate, acetate and dissolved organic carbon found at the Lost City hydrothermal field. Geochim. Cosmochim. Acta 74, 941-952. doi: 10.1016/j.gca.2009.10.045

LaRowe, D. E., and Amend, J. P. (2015). Power limits for microbial life. Front. Microbiol. 6:718. doi: 10.3389/fmicb.2015.00718

LaRowe, D. E., Dale, A. W., Aguilera, D. R., L'Heureux, I., Amend, J. P., and Regnier, P. (2014). Modeling microbial reaction rates in a submarine hydrothermal vent chimney wall. Geochim. Cosmochim. Acta 124, 72-97. doi: 10.1016/j.gca.2013.09.005

LaRowe, D. E., Dale, A. W., Amend, J. P., and Van Cappellen, P. (2012). Thermodynamic limitations on microbially catalyzed reaction rates. Geochim. Cosmochim. Acta 90, 96-109. doi: 10.1016/j.gca.2012.05.011

Leloup, J., Fossing, H., Kohls, K., Holmkvist, L., Borowski, C., and Jørgensen, B. B. (2009). Sulfate-reducing bacteria in marine sediment (Aarhus Bay, Denmark): abundance and diversity related to geochemical zonation. Environ. Microbiol. 11, 1278-1291. doi: 10.1111/j.1462-2920.2008.01855.x

Leloup, J., Loy, A., Knab, N. J., Borowski, C., Wagner, M., and Jørgensen, B. B. (2007). Diversity and abundance of sulfate-reducing microorganisms in the sulfate and methane zones of a marine sediment, Black Sea. Environ. Microbiol. 9, 131-142. doi: 10.1111/j.1462-2920.2006.01122.x

Leskovac, V. (2003). Comprehensive Enzyme Kinetics. New York, NY: Kluwer Academic Publishers.

Lever, M. A., Rogers, K. L., Lloyd, K. G., Overmann, J., Schink, B., Thauer, R. K., et al. (2015). Life under extreme energy limitation: a synthesis of laboratoryand field-based investigations. FEMS Microbiol. Rev. 39, 688-728. doi: 10.1093/ femsre/fuv020

Lin, Y.-S., Biddle, J. F., Lipp, J. S., Orcutt, B. N., Holler, T., Teske, A., et al. (2010). Effect of storage conditions on archaeal and bacterial communities in subsurface marine sediments. Geomicrobiol. J. 27, 261-272. doi: $10.1080 / 01490450903410423$

Lloyd, K. G., Edgcomb, V. P., Molyneaux, S. J., Böer, S., Wirsen, C. O., Atkins, M. S., et al. (2005). Effects of dissolved sulfide, $\mathrm{pH}$, and temperature on growth and survival of marine hyperthermophilic archaea. Appl. Environ. Microbiol. 71, 6383-6387. doi: 10.1128/AEM.71.10.6383-6387.2005

Lovley, D. R., Dwyer, D. F., and Klug, M. J. (1982). Kinetic analysis of competition between sulfate reducers and methanogens for hydrogen in sediments. Appl. Environ. Microbiol. 43, 1373-1379.

Lovley, D. R., and Goodwin, S. (1988). Hydrogen concentrations as an indicator of the predominant terminal. Geochim. Cosmochim. Acta 52, 2993-3003. doi: 10.1016/0016-7037(88)90163-9

Lovley, R., and Klug, M. J. (1986). Model for the distribution of sulfate reduction and methanogenesis in freshwater sedimentst. Geochim. Cosmochim. Acta 50, 11-18. doi: 10.1016/0016-7037(86)90043-8
McCollom, T. M., and Amend, J. P. (2005). A thermodynamic assessment of energy requirements for biomass synthesis by chemolithoautotrophic microorganisms in oxic and anoxic environments. Geobiology 3, 135-144. doi: 10.1111/j.1472-4669.2005.00045.x

McCollom, T. M., and Shock, E. L. (1997). Geochemical constraints on chemolithoautotrophic metabolism by microorganisms in seafloor hydrothermal systems. Geochim. Cosmochim. Acta 61, 4375-4391. doi: 10.1016/S0016-7037(97)00241-X

Muyzer, G., and Stams, A. J. M. (2008). The ecology and biotechnology of sulphatereducing bacteria. Nat. Rev Microbiol. 6, 441-544. doi: 10.1038/nrmicro1892

Nakagawa, S., Takai, K., Inagaki, F., Hirayama, H., Nunoura, T., Horikoshi, K., et al. (2005). Distribution, phylogenetic diversity and physiological characteristics of epsilon-Proteobacteria in a deep-sea hydrothermal field. Environ. Microbiol. 7, 1619-1632. doi: 10.1111/j.1462-2920.2005.00856.x

Newport, P. J., and Nedwell, D. B. (1988). The mechanisms of inhibition of Desulfovibrio and Desulfotomaculum species by selenate and molybdate. J. Appl. Microbiol. 65, 419-423.

Okabe, S., Nielsen, P. H., Jones, W. L., and Characklis, W. G. (1995). Sulfide product inhibition of Desulfovibrio desulfuricans in batch and continuous cultures. Water Res. 29, 571-578. doi: 10.1016/0043-1354(94)00177-9

Oleszkiewicz, J. A., Marstaller, T., and McCartney, D. M. (1989). Effects of pH on sulfide toxicity to anaerobic processes. Environ. Technol. Lett. 10, 815-822. doi: 10.1080/09593338909384801

Olins, H. C., Rogers, D. R., Frank, K. L., Vidoudez, C., and Girguis, P. R. (2013). Assessing the influence of physical, geochemical and biological factors on anaerobic microbial primary productivity within hydrothermal vent chimneys. Geobiology 11, 279-293. doi: 10.1111/gbi.12034

Orcutt, B., Boetius, A., Elvert, M., Samarkin, V., and Joye, S. B. (2005). Molecular biogeochemistry of sulfate reduction, methanogenesis and the anaerobic oxidation of methane at Gulf of Mexico cold seeps. Geochim. Cosmochim. Acta 69, 4267-4281. doi: 10.1016/j.gca.2005.04.012

Oremland, R. S., and Polcin, S. (1982). Methanogenesis and sulfate reduction: competitive and noncompetitive substrates in estuarine sediments. Appl. Environ. Microbiol. 44, 1270-1276.

Oremland, R. S., and Taylor, B. F. (1977). Sulfate reduction and methanogenesis in marine sediments. Geochim. Cosmochim. 42, 209-214. doi: 10.1016/00167037(78)90133-3

Pagé, A., Tivey, M. K., Stakes, D. S., and Reysenbach, A. L. (2008). Temporal and spatial archaeal colonization of hydrothermal vent deposits. Environ. Microbiol. 10, 874-884. doi: 10.1111/j.1462-2920.2007.01505.x

Pallud, C., and Van Cappellen, P. (2006). Kinetics of microbial sulfate reduction in estuarine sediments. Geochim. Cosmochim. Acta 70, 1148-1162. doi: 10.1016/j.gca.2005.11.002

Piłsyk, S., and Paszewski, A. (2009). Sulfate permeases-phylogenetic diversity of sulfate transport. Acta Biochim. Pol. 56, 375-384.

Rabus, R., Hansen, T. A., and Widdel, F. (2006). Dissimilatory sulfate and sulfur reducing prokaryotes. Prokaryotes 2, 659-768. doi: 10.1007/0-387-30742-7_22

Ramos, A. R., Keller, K. L., Wall, J. D., and Pereira, I. A. C. (2012). The membrane QmoABC complex interacts directly with the dissimilatory adenosine 5' phosphosulfate reductase in sulfate reducing bacteria. Front. Microbiol. 3:137. doi: $10.3389 /$ fmicb.2012.00137

Ravenschlag, K., Sahm, K., Knoblauch, C., Jørgensen, B. B., and Amann, R. (2000). Community structure, cellular rRNA content, and activity of sulfate-reducing bacteria in marine Arctic sediments. Appl. Environ. Microbiol. 66, 3592-3602. doi: 10.1128/AEM.66.8.3592-3602.2000

Reeves, E. P., McDermott, J. M., and Seewald, J. S. (2014). The origin of methanethiol in midocean ridge hydrothermal fluids. Proc. Natl. Acad. Sci. U.S.A. 111, 5474-5479. doi: 10.1073/pnas.1400643111

Reis, M., a, Almeida, J. S., Lemos, P. C., and Carrondo, M. J. (1992). Effect of hydrogen sulfide on growth of sulfate reducing bacteria. Biotechnol. Bioeng. 40, 593-600. doi: 10.1002/bit.260400506

Robador, A., Brüchert, V., and Jørgensen, B. B. (2009). The impact of temperature change on the activity and community composition of sulfate-reducing bacteria in arctic versus temperate marine sediments. Environ. Microbiol. 11, 1692-1703. doi: 10.1111/j.1462-2920.2009. 01896.x

Robador, A., Jungbluth, S. P., LaRowe, D. E., Bowers, R. M., Rappé, M. S., Amend, J. P., et al. (2015). Activity and phylogenetic diversity of sulfate-reducing 
microorganisms in low-temperature subsurface fluids within the upper oceanic crust. Front. Microbiol. 5:748. doi: 10.3389/fmicb.2014.00748

Robigou, V., Delaney, J. R., and Stakes, D. S. (1993). Large massive sulfide deposits in a newly disocvered active hydrothermal system, the high rise field, endeavour segment Juan de Fuca ridge. Geophys. Res. Lett. 20, 1887-1890. doi: 10.1029/93GL01399

Rogers, K. L., and Amend, J. P. (2006). Energetics of potential heterotrophic metabolisms in the marine hydrothermal system of Vulcano Island, Italy. Geochim. Cosmochim. Acta 70, 6180-6200. doi: 10.1016/j.gca.2006.08.046

Roychoudhury, A. N. (2004). Sulfate respiration in extreme environments: a Kinetic Study. Geomicrobiol. J. 21, 33-43. doi: 10.1080/01490450490253446

Roychoudhury, A. N., Van Cappellen, P., Kostka, J. E., and Viollier, E. (2003). Kinetics of microbially mediated reactions: dissimilatory sulfate reduction in saltmarsh sediments (Sapelo Island, Georgia, USA). Estuar. Coast. Shelf Sci. 56, 1001-1010. doi: 10.1016/S0272-7714(02)00325-6

Røy, H., Weber, H. S., Tarpgaard, I. H., Ferdelman, T. G., and Jørgensen, B. B. (2014). Determination of dissimilatory sulfate reduction rates in marine sediment via radioactive 35S tracer. Limnol. Oceanogr. Methods 12, 196-211. doi: 10.4319/lom.2014.12.196

Saleh, A. M., Macpherson, R., and Miller, J. D. A. (1964). The effect of inhibitors on sulphate reducing bacteria: a compilation. J. Appl. Microbiol. 27, 281-293. doi: 10.1111/j.1365-2672.1964.tb04914.x

Sani, R. K., Sani, R. K., Peyton, B. M., Peyton, B. M., Brown, L. T., and Brown, L. T. (2001). Copper-induced inhibition of growth of Desulofovibrio desulfuricans G20: assessment of its toxicity and correlation with those of zinc and lead. Appl. Environ. Microbiol. 67, 4765-4772. doi: 10.1128/AEM.67.10.4765-4772.2001

Schrenk, M. O., Kelley, D. S., Delaney, J. R., and Baross, J. A. (2003). Incidence and diversity of microorganisms within the walls of an active deep-Sea sulfide chimney. Appl. Environ. Microbiol. 69, 3580-3592. doi: 10.1128/AEM.69.6.3580-3592.2003

Shock, E. L. (1995). Organic acid in hydrothermal solutions: standard molal thermodynamic properties of carboxylic acids and estimates of dissociation constants at high temperatures and pressures. Am. J. Sci. 295, 496-580. doi: 10.2475/ajs.295.5.496

Shock, E. L., and Koretsky, C. M. (1993). Metal-organic complexes in geochemical processes: calculation of standard partial molal thermodynamic properties of aqueous acetate complexes at high pressures and temperatures. Geochim. Cosmochim. Acta 57, 4899-4922. doi: 10.1016/0016-7037(93)90128-J

Skoog, A., Vlahos, P., Rogers, K. L., and Amend, J. P. (2007). Concentrations, distributions, and energy yields of dissolved neutral aldoses in a shallow hydrothermal vent system of Vulcano, Italy. Org. Geochem. 38, 1416-1430. doi: 10.1016/j.orggeochem.2007.03.005

Slobodkina, G. B., Kolganova, T. V., Querellou, J., Bonch-Osmolovskaya, E. A., and Slobodkin, A. I. (2009). Geoglobus acetivorans sp. nov., an iron(III)-reducing archaeon from a deep-sea hydrothermal vent. Int. J. Syst. Evol. Microbiol. 59, 2880-2883. doi: 10.1099/ijs.0.011080-0

Sokolova, T., Hanel, J., Onyenwoke, R. U., Reysenbach, A.-L., Banta, A., Geyer, R., et al. Wiegel, J. (2007). Novel chemolithotrophic, thermophilic, anaerobic bacteria Thermolithobacter ferrireducens gen. nov., sp. nov. and Thermolithobacter carboxydivorans sp. nov. Extremophiles 11, 145-157. doi: 10.1007/s00792-006-0022-5

Sonne-hansen, J., and Westermann, P. (1999). Kinetics of sulfate and hydrogen uptake by the thermophilic sulfate-reducing bacteria Thermodesulfobacterium sp. strain R1Ha3. Appl. Environ. Microbiol. 65, 1304-1307.

Takai, K., Komatsu, T., Inagaki, F., and Horikoshi, K. (2001). Distribution of archaea in a black smoker chimney structure. Appl. Environ. Microbiol. 67, 3618-3629. doi: 10.1128/AEM.67.8.3618-3629.2001

Takai, K., Sugai, A., Itoh, T., and Horikoshi, K. (2000). Palaeococcus ferrophilus gen. nov., sp. nov., a barophilic, hyperthermophilic archaeon from a deepsea hydrothermal vent chimney. Int. J. Syst. Evol. Microbiol. 50, 489-500. doi: 10.1099/00207713-50-2-489

Tarpgaard, I. H., Roy, H., and Jørgensen, B. B. (2011). Concurrent low- and highaffinity sulfate reduction kinetics in marine sediment. Geochim. Cosmochim. Acta 75, 2997-3010. doi: 10.1016/j.gca.2011.03.028

Temple, K. L., and Le Roux, N. W. (1964). Syngenesis of sulfide ores; sulfate-reducing bacteria and copper toxicity. Econ. Geol. 59, 271-278. doi: 10.2113/gsecongeo.59.2.271

Tivey, M. (2004). "Environmental conditions within active seafloor vent structures: sensitivity to vent fluid composition and fluid flow," in Subseafloor Biosphere at Mid-Ocean Ridges, Geophysical Monograph Series, No. 144, eds W. Wilcock, C. Cary, E. DeLong, D. Kelley, and J. Baross (Washington, DC:American Geophysical Union), 137-152.

Tivey, M. A., Johnson, H. P., and Hole, W. (2002). Crustal magnetization reveals subsurface structure of Juan de Fuca Ridge hydrothermal vent fields. Geology 30, 979-982. doi: 10.1130/0091-7613(2002)030<0979:CMRSSO > 2.0.CO;2

Tivey, M. K. (1995). The influence of hydrothermal fluid composition and advection rates on black smoker chimney mineralogy: insights from modeling transport and reaction. Geochim. et Cosmochim. Acta 59, 1933-1949. doi: 10.1016/0016-7037(95)00118-2

Tivey, M. K., and Delaney, J. R. (1986). Growth of large sulfide structures on the endeavour segment of the Juan de Fuca ridge. Earth Planet. Sci. Lett. 77, 303-317. doi: 10.1016/0012-821X(86)90142-1

Tivey, M. K., Stakes, D. S., Cook, T. L., Hannington, M. D., and Petersen, S. (1999). A model for growth of steep-sided vent structures on the Endeavour Segment of the Juan de Fuca Ridge: results of a petrologic and geochemical study. J. Geophys. Res. 104, 22859-22883. doi: 10.1029/1999JB900107

Treude, T., Smith, C., Wenzhöfer, F., Carney, E., Bernardino, A., Hannides, A., et al. (2009). Biogeochemistry of a deep-sea whale fall: sulfate reduction, sulfide efflux and methanogenesis. Mar. Ecol. Prog. Ser. 382, 1-21. doi: 10.3354/meps07972

Trüper, H. G., and Rogers, L. A. (1971). Purification and properties of adenylyl sulfate reductase from the phototrophic sulfur bacterium, Thiocapsa roseopersicina. J. Bacteriol. 108, 1112-1121.

Utgikar, V., Harmon, S. M., Chaudhary, N., Tabak, H. H., Govind, R., and Haines, J. R. (2002). Inhibition of sulfate-reducing bacteria by metal sulfide formation in bioremediation of acid mine drainage. Environ. Toxicol. 17, 40-48. doi: 10.1002/tox.10031

Utgikar, V. P., Tabak, H. H., Haines, J. R., and Govind, R. (2003). Quantification of toxic and inhibitory impact of copper and zinc on mixed cultures of sulfatereducing bacteria. Biotechnol. Bioeng. 82, 306-312. doi: 10.1002/bit.10575

Weber, A., and Jørgensen, B. B. (2002). Bacterial sulfate reduction in hydrothermal sediments of the Guaymas Basin, Gulf of California, Mexico. Deep. Res. I Oceanogr. Res. Pap. 49, 827-841. doi: 10.1016/S0967-0637(01)00079-6

Weijma, J., Stams, A. J., Hulshoff Pol, L. W., and Lettinga, G. (2000). Thermophilic sulfate reduction and methanogenesis with methanol in a high rate anaerobic reactor. Biotechnol. Bioeng. 67, 354-363. doi: 10.1002/(SICI)10970290(20000205)67:3<354::AID-BIT12>3.0.CO;2-X

Westrich, J. T., and Berner, R. A. (1984). The role of sedimentary organic matter in bacterial sulfate reduction: the G model tested. Limnol. Oceanogr. 29, 236-249. doi: 10.4319/lo.1984.29.2.0236

Wolery, T. J. (1992a). EQ3/6, A Software Package for Geochemical Modeling of Aqueous Systems: Package Overview and Installation Guide (Version 7. 0). Livermore, CA: Lawrence Livermore National Laboratory.

Wolery, T. J. (1992b). EQ3NR, a Computer Program for Geochemical Aqueous Speciation-solubility Calculations: Theoretical Manual, User's Guide and Related Documentation (Version 7.0). Livermore, CA: Lawrence Livermore Laboratory, University of California.

Wolery, T. J., and Daveler, S. A. (1992). EQ6, a Computer Program for Reaction Path Modeling of Aqueous Geochemical Systems: Theoretical Manual, User's Guide and Related Documentation (Version 7.0). Livermore, CA: Lawrence Livermore Laboratory, University of California.

Xu, N., Christodoulatos, C., and Braida, W. (2006). Adsorption of molybdate and tetrathiomolybdate onto pyrite and goethite: effect of $\mathrm{pH}$ and competitive anions. Chemosphere 62, 1726-1735. doi: 10.1016/j.chemosphere.2005.06.025

Zhu, W., Tivey, M. K., Gittings, H., and Craddock, P. R. (2007). Permeabilityporosity relationships in seafloor vent deposits: dependence on pore evolution processes. J. Geophys. Res. 112, 1-15. doi: 10.1029/2006jb004716

Conflict of Interest Statement: The authors declare that the research was conducted in the absence of any commercial or financial relationships that could be construed as a potential conflict of interest.

Copyright (c) 2015 Frank, Rogers, Rogers, Johnston and Girguis. This is an open-access article distributed under the terms of the Creative Commons Attribution License (CC $B Y)$. The use, distribution or reproduction in other forums is permitted, provided the original author(s) or licensor are credited and that the original publication in this journal is cited, in accordance with accepted academic practice. No use, distribution or reproduction is permitted which does not comply with these terms. 